\title{
Evaluation of the new capture vapourizer for aerosol mass spectrometers (AMS) through laboratory studies of inorganic species
}

\author{
Weiwei Hu ${ }^{1,2}$, Pedro Campuzano-Jost ${ }^{1,2}$, Douglas A. Day ${ }^{1,2}$, Philip Croteau ${ }^{3}$, Manjula R. Canagaratna ${ }^{3}$, \\ John T. Jayne ${ }^{3}$, Douglas R. Worsnop ${ }^{3}$, and Jose L. Jimenez ${ }^{1,2}$ \\ ${ }^{1}$ Cooperative Institute for Research in the Environmental Sciences (CIRES), University of Colorado at Boulder, \\ 216 UCB, Boulder, CO 80309, USA \\ ${ }^{2}$ Department of Chemistry \& Biochemistry, University of Colorado at Boulder, 216 UCB, Boulder, CO 80309, USA \\ ${ }^{3}$ Aerodyne Research, Inc., Billerica, Massachusetts, USA
}

Correspondence to: Jose L. Jimenez (jose.jimenez@ colorado.edu)

Received: 8 October 2016 - Discussion started: 9 November 2016

Revised: 23 May 2017 - Accepted: 8 July 2017 - Published: 15 August 2017

\begin{abstract}
Aerosol mass spectrometers (AMSs) and Aerosol Chemical Speciation Monitors (ACSMs) commercialized by Aerodyne are widely used to measure the non-refractory species in submicron particles. With the standard vapourizer (SV) that is installed in all commercial instruments to date, the quantification of ambient aerosol mass concentration requires the use of the collection efficiency (CE) to correct for the loss of particles due to bounce. A new capture vapourizer (CV) has been designed to reduce the need for a bouncerelated $\mathrm{CE}$ correction.

Two high-resolution AMS instruments, one with a SV and one with a $\mathrm{CV}$, were operated side by side in the laboratory. Four standard species, $\mathrm{NH}_{4} \mathrm{NO}_{3}, \mathrm{NaNO}_{3},\left(\mathrm{NH}_{4}\right)_{2} \mathrm{SO}_{4}$ and $\mathrm{NH}_{4} \mathrm{Cl}$, which typically constitute the majority of the mass of ambient submicron inorganic species, are studied. The effect of vapourizer temperature $\left(T_{\mathrm{V}} \sim 200-800^{\circ} \mathrm{C}\right)$ on the detected fragments, $\mathrm{CE}$ and size distributions are investigated. A $T_{\mathrm{V}}$ of $500-550^{\circ} \mathrm{C}$ for the $\mathrm{CV}$ is recommended. In the $\mathrm{CV}, \mathrm{CE}$ was identical (around unity) for more volatile species (e.g. $\mathrm{NH}_{4} \mathrm{NO}_{3}$ ) and comparable to or higher than the $\mathrm{SV}$ for less-volatile species (e.g. $\left.\left(\mathrm{NH}_{4}\right)_{2} \mathrm{SO}_{4}\right)$, demonstrating an improvement in $\mathrm{CE}$ for laboratory inorganic species in the $\mathrm{CV}$. The detected relative intensities of fragments of $\mathrm{NO}_{3}$ and $\mathrm{SO}_{4}$ species observed with the $\mathrm{CV}$ are different from those observed with the SV, and are consistent with additional thermal decomposition arising from the increased residence time and multiple collisions. Increased residence times with the
\end{abstract}

$\mathrm{CV}$ also lead to broader particle size distribution measurements than with the SV. A method for estimating whether pure species will be detected in AMS sizing mode is proposed. Production of $\mathrm{CO}_{2}(\mathrm{~g})$ from sampled nitrate on the vapourizer surface, which has been reported for the $\mathrm{SV}$, is negligible for the $\mathrm{CV}$ for $\mathrm{NH}_{4} \mathrm{NO}_{3}$ and comparable to the $\mathrm{SV}$ for $\mathrm{NaNO}_{3}$. We observe an extremely consistent fragmentation for ammonium compared to very large changes for the associated anions. Together with other evidence, this indicates that it is unlikely that a major fraction of inorganic species vapourizes as intact salts in the AMS.

\section{Introduction}

Submicron aerosols have major effects on climate and human health (Hallquist et al., 2009; Heal et al., 2012; IPCC, 2013; Fuzzi et al., 2015). In recent decades, various new instruments have been developed to measure different properties of fine aerosols (Turpin et al., 2000; Farmer and Jimenez, 2010). Among them, Aerodyne aerosol mass spectrometers (AMS, produced by Aerodyne Research Inc., Billerica, MA, USA) have emerged as one of the most commonly used online aerosol composition instruments due to their fast response ( $\sim$ seconds to minutes) and ability to quantify the bulk chemical composition and size distribution of submicron nonrefractory aerosols, i.e. organic aerosol, sulfate, ammonium, 
nitrate and chloride (Jayne et al., 2000; Allan et al., 2003a, b; Canagaratna et al., 2007; Jimenez et al., 2009, and references therein).

Comparisons between AMS and other co-located aerosol instruments in various field studies (Drewnick et al., 2003, 2004b; Allan et al., 2004a; Takegawa et al., 2009; Docherty et al., 2011; Middlebrook et al., 2012) or laboratory studies (Bahreini et al., 2005; Matthew et al., 2008; Docherty et al., 2012) have shown that, despite the typically strong correlation between AMS and other aerosol instrument measurements, a correction factor needs to be used for mass quantification in the AMS. This factor is known to be due predominately to the AMS collection efficiency (CE), which is the ratio between the concentration of particles detected in AMS and the concentration of particles introduced to the AMS inlet (Huffman et al., 2005; Matthew et al., 2008). CE $<1$ in the AMS can be due to particle loss within the (1) aerodynamic lens $\left(E_{\mathrm{L}}\right)$, depending on particle size, lens design and pressure (Jayne et al., 2000; Liu et al., 2007; Bahreini et al., 2008); (2) particle time-of-flight (PToF) chamber $\left(E_{\mathrm{S}}\right)$ caused by non-spherical particles that result in broader particle beams with some particles not reaching the vapourizer (Huffman et al., 2005; Salcedo et al., 2007), or (3) particle bounce on the vapourizer $\left(E_{\mathrm{B}}\right)$. The final $\mathrm{CE}$ is the product of these three factors $\left(\mathrm{CE}=E_{\mathrm{L}} \times E_{\mathrm{S}} \times E_{\mathrm{B}}\right.$ ) (Huffman et al., 2005). Multiple laboratory and field measurements have shown that $E_{\mathrm{L}}$ and $E_{\mathrm{S}}$ are typically near unity for submicron particles, whereas $E_{\mathrm{B}}$ is the dominant term (Matthew et al., 2008; Middlebrook et al., 2012). All AMS commercial instruments to date have used a standard vapourizer (SV), shaped as an inverted cone of porous tungsten, and kept at vapourizer temperature $\left(T_{\mathrm{v}}\right)$ of $\sim 550-600^{\circ} \mathrm{C}$ for ambient measurements (and most laboratory measurements).

Various factors, including RH in the sampling line, aerosol water content, aerosol acidity/neutralization of sulfate content and ammonium nitrate fraction in total aerosol, can influence CE, and thus aerosol quantification in the AMS (Quinn et al., 2006; Middlebrook et al., 2012). CE in the SV is in the range 0.2-0.4 for pure ammonium sulfate (Drewnick et al., 2004a; Weimer et al., 2006; Takegawa et al., 2009) and $\sim 1$ for pure ammonium nitrate (Jayne et al., 2000; Middlebrook et al., 2012). A parameterization of $\mathrm{CE}$ for ambient particles based on composition has been used successfully in many environments (Middlebrook et al., 2012), but the remaining uncertainties on $\mathrm{CE}$ are thought to dominate the uncertainty of AMS concentration measurements (Bahreini et al., 2009)

Efforts aiming to minimize the uncertainty of aerosol mass spectrometers have been conducted recently. Using the differential mobility analyser (DMA) coupled to an impactor to quantify the particle bounce fraction, Kang et al. (2015) tested different metal materials, vapourizer porosities and shapes for particle bouncing and found copper, meshed/porous surface, as well as reversed T-shape materials best at reducing the particle bounce fraction. Each version can reduce the bounce fraction by around $10-50 \%$ com- pared to the basic set up, indicating that CE can be improved through vapourizer design. A custom instrument similar to the AMS has a different design of particle trap/vapourizer to increase CE (Takegawa et al., 2012; Ozawa et al., 2016). A regression slope of 0.7 for sulfate, probably caused by different size cuts in a field study, was observed between this and other instruments.

A capture vapourizer $(\mathrm{CV})$ has been recently developed by Aerodyne (Jayne and Worsnop, 2016) to achieve CE $=1$ for ambient particles in the AMS; hence it decrease the quantification uncertainty (Xu et al., 2017). We have performed laboratory studies to evaluate the performance and detection characteristics of the $\mathrm{CV}$ for key inorganic species, i.e. $\mathrm{NH}_{4} \mathrm{NO}_{3}$, $\mathrm{NaNO}_{3},\left(\mathrm{NH}_{4}\right)_{2} \mathrm{SO}_{4}$ and $\mathrm{NH}_{4} \mathrm{Cl}$. We compare fragmentation patterns, $\mathrm{CE}$ and particle size distributions as a function of $T_{\mathrm{V}}\left(=200-800^{\circ} \mathrm{C}\right)$ in both the SV and CV. This is the first time that the performance of laboratory-generated inorganic aerosol in AMS with the SV and CV over a wide range of $T_{\mathrm{V}}$ $\left(200-800^{\circ} \mathrm{C}\right)$ has been reported. Recommendations for optimal $T_{\mathrm{v}}$ and fragmentation table modifications for the CV are given. Fragmentation and quantification of $\mathrm{NH}_{4} \mathrm{NO}_{3}$ as a function of particle beam position on the vapourizers is also investigated. Pieber et al. (2016) recently showed that inorganic salts can produce $\mathrm{CO}_{2}(\mathrm{~g})$ from material that is accumulated on the surface of the AMS in the SV, and we investigate whether this effect is observed for the CV.

\section{Experimental set-up and instrumentation}

\subsection{Brief description of the capture vapourizer}

The detailed design of the $\mathrm{CV}$ has been presented in $\mathrm{Xu}$ et al. (2017); thus only a brief description is provided here. Both the SV and CV are based on cartridge heaters, which are resistively heated by passing power through a $\sim 0.1 \mathrm{~mm}$ diameter coiled tungsten wire positioned inside of the tube (Jayne et al., 2000; Canagaratna et al., 2007; Xu et al., 2017). The CV tube length is about double that of the SV (Fig. S1 in the Supplement). The particle impact surface of the SV is an inverted cone, whereas the CV is designed to have a cage inside the vapourizer with a narrow entrance (Fig. 1a) to minimize particle bouncing loss. The $\mathrm{SV}$ is constructed from $80 \%$ dense porous tungsten, while the $\mathrm{CV}$ is solid molybdenum.

\subsection{Laboratory measurement set-up}

Laboratory experiments in this study were set up as shown in Fig. 1b. Pure inorganic salt particles were generated with a Collison atomizer (model: 3076; TSI, US) from their dilute water solutions. Atomized particles were dried with a Nafion (MD-110-24S-4, Perma Pure LCC, US) or a silica gel diffusion dryer $(\mathrm{RH}<30 \%)$, and then were size selected by a differential mobility analyser (DMA, model: 3080, TSI, US). To remove multiple charged particles (required for accu- 
(a)

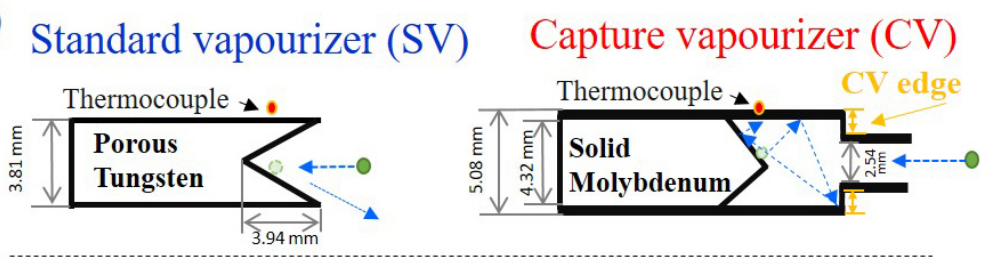

(b)

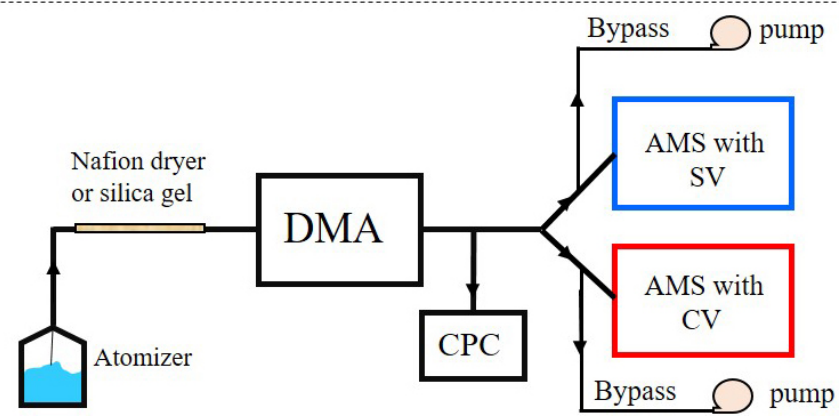

Figure 1. (a) Schematic diagrams of the standard vapourizer (SV) and capture vapourizer (CV). More details of the CV design can be found in Xu et al. (2017). The appearance of the SV and CV are shown in Fig. S1. (b) Set up of laboratory experiments for comparing the SV and $\mathrm{CV}$. The sampling gas was kept below $30 \% \mathrm{RH}$ by Nafion dryers and/or silica gel diffusion dryers.

rate quantification), impactors with different sizes (i.e. 0.071 , 0.0508 or $0.0457 \mathrm{~cm}$ for $0.6-0.75 \mathrm{~L} \mathrm{~min}^{-1}$ aerosol sampling flow) were used upstream of the DMA. The particle cut sizes of those impactors varied with flow rate and particle properties, which can be calculated using Aerosol Instrument Manager (AIM) from TSI. The mass-based size distribution from SV suggested the doubly charged particle mass fractions are less than $10 \%$ in all cases (Sect. 3.3, Figs. 12-13). Finally, the monodisperse particles were measured by two nominally identical high-resolution time-of-flight AMS (HRToF-AMS) equipped with the SV and CV respectively. Particle number concentration was determined with a condensation particle counter (CPC, model: 3760 or 3010, TSI, US) sampling in parallel to the AMSs. The mass concentrations can be calculated from the CPC and size data.

The volume flow rate into the AMS was $\sim 0.1 \mathrm{~L} \mathrm{~min}^{-1}$. A bypass flow $\left(0.2-0.3 \mathrm{~L} \mathrm{~min}^{-1}\right)$ near the inlet of each AMS was added to reduce time in the tubing and thus reduce particle losses. Sampling tubes were usually copper or stainless steel with 1/4 inch outer diameter. All of the standard inorganic chemical compounds used in this study were analytical grade (purity $>99.9 \%$ ). Water used was either NERL reagent grade water from Thermo Scientific Inc. (USA) or milli-Q water purified by a Milli-Q Integral Water Purification System (EMD Millipore Corporation, Germany).

\subsection{AMS measurements}

In this study, most of the comparison experiments were conducted using HR-ToF-AMSs (DeCarlo et al., 2006). The one exception was the lens alignment experiment for the SV, which was carried out in a quadrupole AMS (Q-AMS, Jayne et al., 2000). All the instruments used for these experiments have the same chamber length (chopper to vapourizer distance: $295 \mathrm{~mm}$ ), while the Q-AMS had a longer chamber $(395 \mathrm{~mm})$. ToF-AMS data were analysed with the standard software packages (Squirrel version $\geq 1.52 \mathrm{M}$ and PIKA ver$\operatorname{sion} \geq 1.12$ ). The Q-AMS data were analysed with the QAMS analysis toolkit (version 1.43). All the ToF MS mode data used in this study were high-resolution (HR) data, and PToF data were unit mass resolution (UMR) data.

Before each set of experiments, a lens alignment was performed on each AMS. Mass concentrations of detected aerosols were obtained from the MS-mode signal, which is the difference in signal between chopper blocking and not blocking the particle beam: beam open ( 6 or $5 \mathrm{~s}$ ) minus beam closed (4 or $5 \mathrm{~s}$ ) (Jimenez et al., 2003). The ionization and detection efficiency (IE) of nitrate and the relative ionization efficiency (RIE) of ammonium were calibrated with dry monodisperse $400 \mathrm{~nm}$ ammonium nitrate $\left(\mathrm{NH}_{4} \mathrm{NO}_{3}\right)$ particles every few days during the laboratory studies (Canagaratna et al., 2007). Both BFSP (brute-force single particle mode; DeCarlo et al., 2006) and methods based on CPC measurements (described above) were applied to the SV AMS, while only the latter method was applied to the CV AMS.

It is not possible to apply the BFSP method to the CV AMS due to the longer residence time of vapourized molecules in the $\mathrm{CV}$ resulting in a broadening of singleparticle pulse so that their signal cannot be sufficiently discriminated from the noise, at least for particles of sizes that

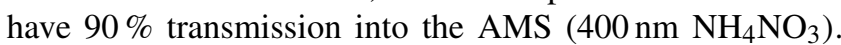
The escape time of $\mathrm{NH}_{4} \mathrm{NO}_{3}$ vapours from the $\mathrm{CV}$ is larger than $200 \mu$ s (see Sect. 3.1.4), which is much longer than the measured duration of single particle events of $\mathrm{NH}_{4} \mathrm{NO}_{3}$ in the SV of $\sim 25-40 \mu$ s (Drewnick et al., 2015). For other species such as $\left(\mathrm{NH}_{4}\right)_{2} \mathrm{SO}_{4}$, an additional cause of broad- 
ening is due to additional particle collisions inside the $\mathrm{CV}$ after an initial bounce event.

Most IE calibrations in AMS were carried out simultaneously for both AMSs using the same stream of calibrated particles. Sulfate RIE $\left(\mathrm{RIE}_{\mathrm{SO}_{4}}\right)$ was calibrated with pure ammonium sulfate $\left(\left(\mathrm{NH}_{4}\right)_{2} \mathrm{SO}_{4}\right)$ by measuring the relative response of ammonium in both $\mathrm{NH}_{4} \mathrm{NO}_{3}$ and $\left(\mathrm{NH}_{4}\right)_{2} \mathrm{SO}_{4} . T_{\mathrm{v}}$ in the range of $200-800^{\circ} \mathrm{C}$ were used in both AMSs to investigate the influences of this parameter. Chloride RIE applied in this study is 1.3 .

\subsection{Determination of vapourizer temperature $\left(T_{v}\right)$}

$T_{\mathrm{v}}$ is a function of the electrical power (voltage $\times$ current) supplied to the vapourizer, and is controlled by the electronics box (EBOX) in the AMS. $T_{\mathrm{v}}$ can be quantified in two ways. One method is through a thermocouple attached to the vapourizer body. The relationship between the thermocouple reading and the applied vapourizer power for the SV and CV is shown in Fig. 2a. The curve for the SV was obtained based on a combination of thermocouple-power readings from several different AMSs (Williams, 2010). The thermocouple reading vs. vapourizer power results for the $\mathrm{CV}$ in our AMS were similar to those for the SV when vapourizer power was below 2 watts. However, it was lower when vapourizer power was between 2 and 10 watts. Since the thermocouples were mounted outside the vapourizer body (Figs. 1a and S1) in both vapourizers, neither thermocouple measured the actual surface $T_{\mathrm{V}}$ that the particles encountered but the measured temperature is assumed to be reasonably close. The thermocouple reading method usually works well for newly installed vapourizers. However, with vapourizer aging, the thermocouple often becomes detached and hence reports a lower $T_{\mathrm{v}}$ reading than the true values (Williams, 2010). The input vapourizer power, on the other hand, is likely to be more reliable than the thermocouple reading in most of the conditions.

Thus, an alternative method to determine $T_{\mathrm{v}}$ without the thermocouple can be useful. Williams (2010) reported that the measured size distribution width (quantified as the full width at half maximum, $\mathrm{FWHM}$ ) of the $\mathrm{NO}_{3}$ signal from monodisperse $\mathrm{NaNO}_{3}$ particles starts to broaden at $T_{\mathrm{v}}$ below $600^{\circ} \mathrm{C}\left( \pm 50^{\circ} \mathrm{C}\right)$ for $\mathrm{SV}$. The $T_{\mathrm{v}}$ broadening is defined as the point at which the size distribution width increases above $20 \%$ of the lowest peak width, which was determined by averaging peak width values when vapourizer power is above $4.5 \mathrm{~W}$. This broadening was repeatable in different AMS systems and was proposed as a technique to verify $T_{\mathrm{V}}$ settings. This method is expected to allow identification of problems with the thermocouple measurement, since it directly reflects the chemical vapourization properties of a standard compound. In this study, size distributions of monodisperse $300 \mathrm{~nm} \mathrm{NaNO} 3$ particles were measured at different $T_{\mathrm{v}}(300$ $800^{\circ} \mathrm{C}$ ) multiple times (2014-2016). A summary of those results for $\mathrm{NaNO}_{3}$ size distributions of FWHM as a func-
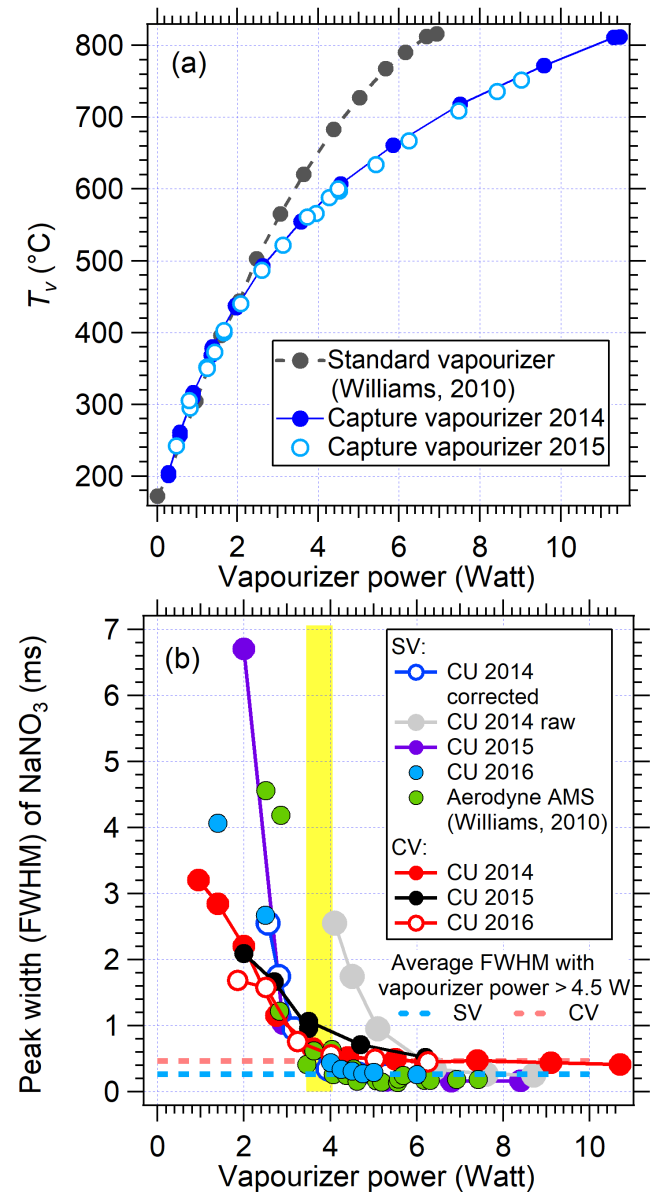

Figure 2. (a) Relationship between vapourizer temperature $\left(T_{\mathrm{V}}\right.$ as reported by the attached thermocouple) and vapourizer power. (b) Peak width of measured size distributions of $300 \mathrm{~nm} \mathrm{NaNO}_{3}$ particles as a function vapourizer power. In (b), the 2014 curve raw (grey trace) between peak width and vapourizer power in the SV indicated that the vapourizer power reading in that AMS system was inaccurate during those tests (see main text). Therefore, a correction (Corrected vapourizer power $=0.6 \times$ displayed vapourizer power +0.1 ), which was obtained by matching the CU 2014 curve to the others from SV, was applied. The yellow background shows the range of vapourizer power between 3.6 and $4 \mathrm{~W}$, where a transition in the detected peak width occurs in both vapourizers. The blue and pink dashed lines are the average values of peak width from $\mathrm{CU}$ 2016 curves of SV and CV (respectively) when vapourizer power is above $4.5 \mathrm{~W}$.

tion of vapourizer power is displayed in Fig. 2b. The FWHM of $\mathrm{NaNO}_{3}$ for the SV in our AMS was consistent with results from Williams (2010). In the 2014 measurements, the broadening threshold temperature of the SV corresponded to a higher nominal vapourizer power than the others. It was found that the AMS electronic box (AMS EBOX) at that time was delivering less power to vapourizer than the readout indicated. Thus, the $T_{\mathrm{v}}$ was corrected by matching the 2014 curve to the others as shown in Fig. 2b. The FWHM as a function of 
$T_{\mathrm{V}}$ in the $\mathrm{CV}$ was consistent among experiments conducted at different instrument conditions during different years, and started to broaden at $\mathrm{CV}$ powers of around $\sim 3.6-4 \mathrm{~W}$, which is similar to the $\mathrm{SV}$. The reported $T_{\mathrm{V}}$ in this paper are based on the relationship of $T_{\mathrm{v}}$ vs. vapourizer power shown in Fig. $2 \mathrm{a}$. Finally, 3.8 and $4.2 \mathrm{~W}$ corresponded to $T_{\mathrm{v}} \approx 600^{\circ} \mathrm{C}$ in the $\mathrm{SV}$ and $\mathrm{CV}$ respectively.

\subsection{SMPS measurements}

SMPS particle sizing was verified with monodisperse polystyrene latex spheres (PSLs) (Duke Scientific, Palo Alto, CA, US) with diameters of 250-400 nm. The SMPS sheath and sample flow rates were calibrated before each set of experiments. Mass concentrations were calculated by multiplying reported volume concentrations with their corresponding densities. The densities used for $\mathrm{NH}_{4} \mathrm{NO}_{3}, \mathrm{NaNO}_{3}$, $\left(\mathrm{NH}_{4}\right)_{2} \mathrm{SO}_{4}$ and $\mathrm{NH}_{4} \mathrm{Cl}$ in this study are 1.72, 2.26, 1.78 and $1.52 \mathrm{~g} \mathrm{~cm}^{-3}$ respectively (Haynes, 2015). A Jayne shape factor of 0.8 was applied to $\mathrm{NH}_{4} \mathrm{NO}_{3}$. This Jayne shape factor was experimentally determined by comparing the mobility and vacuum aerodynamic diameters $\left(d_{\mathrm{va}}\right)$ measured for $\mathrm{NH}_{4} \mathrm{NO}_{3}$ (Jayne et al., 2000; DeCarlo et al., 2004) and used to correct for the fact that the effective density of pure $\mathrm{NH}_{4} \mathrm{NO}_{3}$ particles is less than the bulk density. Possible reasons for this lower effectiveness than bulk density include particle non-sphericity or the formation of a phase of lower density for the aerosols compared to macroscopic $\mathrm{NH}_{4} \mathrm{NO}_{3}$ (DeCarlo et al., 2004). Experimental investigation of the fundamental reasons for the lower effective density of $\mathrm{NH}_{4} \mathrm{NO}_{3}$ compared to the bulk species is recommended.

\section{Results and discussion}

\subsection{Thermal decomposition and fragmentation of standard species}

\subsubsection{Nitrate and sulfate fragmentation patterns}

The fragment ion comparisons of $\mathrm{NH}_{4} \mathrm{NO}_{3}$ and $\left(\mathrm{NH}_{4}\right)_{2} \mathrm{SO}_{4}$ particles in an argon flow (to remove interfering ions from air) between the $\mathrm{SV}$ and $\mathrm{CV}$ for $T_{\mathrm{V}} \sim 500-550{ }^{\circ} \mathrm{C}$ are shown in Table 1. A slightly lower $T_{\mathrm{V}}$ than the standard $600^{\circ} \mathrm{C}$ used in the SV was chosen here. This is because lower $T_{\mathrm{V}}$ is recommended for a general $\mathrm{CV}$ operation, as discussed below in Sect. 3.3.2. The major ions of nitrate in $\mathrm{NH}_{4} \mathrm{NO}_{3}$ are $\mathrm{NO}^{+}$and $\mathrm{NO}_{2}^{+}$, comprising of $\sim 98 \%$ of the signal in the SV and $99 \%$ in the CV (Table 1, Jayne et al., 2000; Allan et al., 2004b; Hogrefe et al., 2004). $\mathrm{NO}_{2}^{+}$and $\mathrm{NO}^{+}$ showed strong linear correlations across a wide range of $\mathrm{NH}_{4} \mathrm{NO}_{3}$ mass concentrations, as expected (Fig. 3a). The ratio of $\mathrm{NO}_{2}^{+} / \mathrm{NO}^{+}$of $\mathrm{NH}_{4} \mathrm{NO}_{3}$ in $\mathrm{SV}$ was $\sim 0.35$ within the range of $\mathrm{NO}_{2}^{+} / \mathrm{NO}^{+}$ratios reported in other studies $(0.29-$ 0.75) (Hogrefe et al., 2004; Bae et al., 2007; Farmer and Jimenez, 2010; Fry et al., 2013). In contrast, in the CV it was only $0.04-0.07$, an order of magnitude lower. The much lower $\mathrm{NO}_{2}^{+} / \mathrm{NO}^{+}$ratios in the $\mathrm{CV}$ than in the $\mathrm{SV}$ are consistent with results of $\mathrm{Xu}$ et al. (2017). To qualitatively interpret this difference, a possible mechanism of $\mathrm{NO}_{2}^{+}$and $\mathrm{NO}^{+}$production in the AMS system is discussed.

Nitrate from $\mathrm{NH}_{4} \mathrm{NO}_{3}$ particles can produce gas-phase $\mathrm{HNO}_{3}(\mathrm{~g}), \mathrm{NO}_{2}(\mathrm{~g})$ and $\mathrm{NO}(\mathrm{g})$ species (Drewnick et al., 2015), as

$$
\begin{aligned}
\mathrm{NH}_{4} \mathrm{NO}_{3}(\mathrm{~s}) & \rightarrow a \times \mathrm{NH}_{3}(\mathrm{~g})+b \times \mathrm{HNO}_{3}(\mathrm{~g}) \\
& +c \times \mathrm{NO}_{2}(\mathrm{~g})+d \times \mathrm{NO}(\mathrm{g})+\text { others }
\end{aligned}
$$

The electron ionization (EI) fragmentation products of $\mathrm{HNO}_{3}(\mathrm{~g})$ and $\mathrm{NO}_{2}(\mathrm{~g})$ at $70 \mathrm{eV}$ are mostly $\mathrm{NO}^{+}$and $\mathrm{NO}_{2}^{+}$, with $\mathrm{NO}_{2}^{+} / \mathrm{NO}^{+}$ratios of $\sim 1.17-2$ and $0.3-0.5$ respectively (Friedel et al., 1959; Linstrom and Mallard, 2016). NO(g) produces almost only $\mathrm{NO}^{+}$, and no $\mathrm{NO}_{2}^{+}$(Linstrom and Mallard, 2016). In the AMS (with SV) the fragments observed are often smaller due to thermal decomposition and fragmentation of hotter ions, given the higher temperatures of the neutrals compared to NIST (National Institute of Standards and Technology; Canagaratna et al., 2015). Taking the NIST ratios as upper limits, the $\mathrm{NO}_{2}^{+} / \mathrm{NO}^{+}$ratio in the $\mathrm{SV}$ (0.29-0.75) might result from a combination of EI ionization from $\mathrm{HNO}_{3}(\mathrm{~g}), \mathrm{NO}_{2}(\mathrm{~g})$ and $\mathrm{NO}(\mathrm{g})$. Pieber et al. (2016) speculated that the $\mathrm{NO}_{2}(\mathrm{~g})$ is an important thermal decomposition product for $\mathrm{NH}_{4} \mathrm{NO}_{3}$ in $\mathrm{SV}$. The $\mathrm{NO}_{2}^{+} / \mathrm{NO}^{+}$ratio in the $\mathrm{CV}(0.04-0.07)$ was much lower than the NIST ratios from $\mathrm{NO}_{2}(\mathrm{~g})$ and $\mathrm{HNO}_{3}(\mathrm{~g})(0.3-2)$, suggesting that the ionization of $\mathrm{NO}(\mathrm{g})$ is likely the major pathway for the $\mathrm{CV}$. The dominance of $\mathrm{NO}(\mathrm{g})$ in the $\mathrm{CV}$ may be due to the longer residence time and increased number of collisions of vapours in the $\mathrm{CV}$, leading to enhanced thermal decomposition. Indeed, $\mathrm{NO}(\mathrm{g})$ is also the favoured thermodynamic product for $T_{\mathrm{V}}$ of $\sim 500-650{ }^{\circ} \mathrm{C}$ (Wang et al., 2015).

A shift to smaller molecular weight ion fragments for the $\mathrm{CV}$ was observed for $\left(\mathrm{NH}_{4}\right)_{2} \mathrm{SO}_{4}$ as well (Fig. 3b). The thermal decomposition products of $\left(\mathrm{NH}_{4}\right)_{2} \mathrm{SO}_{4}$ are shown below:

$$
\begin{gathered}
\left(\mathrm{NH}_{4}\right)_{2} \mathrm{SO}_{4}(\mathrm{~s}) \rightarrow a \times \mathrm{NH}_{3}(\mathrm{~g})+b \times \mathrm{H}_{2} \mathrm{SO}_{4}(\mathrm{~g})+c \times \mathrm{SO}_{3}(\mathrm{~g}) \\
+d \times \mathrm{SO}_{2}(\mathrm{~g})+e \times \mathrm{H}_{2} \mathrm{O}+\text { others. }
\end{gathered}
$$

The major ions from sulfate aerosols in the AMS are $\mathrm{SO}^{+}$, $\mathrm{SO}_{2}^{+}, \mathrm{SO}_{3}^{+}, \mathrm{HSO}_{3}^{+}$and $\mathrm{H}_{2} \mathrm{SO}_{4}^{+}$(Allan et al., 2004b; Hogrefe et al., 2004). Ratios of $\mathrm{SO}_{3}^{+}, \mathrm{HSO}_{3}^{+}$and $\mathrm{H}_{2} \mathrm{SO}_{4}^{+}$to $\mathrm{SO}^{+}$ signal in the $\mathrm{CV}(<0.05)$ were consistently lower than for $\mathrm{SV}(0.11-0.38)$, while $\mathrm{SO}_{2}^{+} / \mathrm{SO}^{+}$showed the opposite trend (1.7-1.8 in CV vs. 1.0-1.5 in SV). This shift indicates that greater thermal decomposition occurs in the $\mathrm{CV}$. The ratios of $\mathrm{SO}_{3}^{+}, \mathrm{HSO}_{3}^{+}$and $\mathrm{H}_{2} \mathrm{SO}_{4}^{+}$vs. $\mathrm{SO}^{+}$from $\mathrm{H}_{2} \mathrm{SO}_{4}(\mathrm{~g})$ in the NIST EI database are 2.0, 1.4 and 0.9 respectively (Linstrom and Mallard, 2016). Given that the ionization process is the same in the AMS and NIST, the much lower ratios of $\mathrm{SO}_{3}^{+}$, $\mathrm{HSO}_{3}^{+}$and $\mathrm{H}_{2} \mathrm{SO}_{4}^{+}$compared to $\mathrm{SO}^{+}$from $\left(\mathrm{NH}_{4}\right)_{2} \mathrm{SO}_{4}$ in the 
Table 1. Fragmentation patterns of particulate nitrate from $\mathrm{NH}_{4} \mathrm{NO}_{3}$ particles and particulate sulfate from $\left(\mathrm{NH}_{4}\right)_{2} \mathrm{SO}_{4}$ particles. Both fragmentation patterns were measured in pure argon gas. The intensity relative to the largest peak and the fraction of total are reported. The uncertainties of the fragment fractions correspond to the variability of the data as 1 standard deviation.

\begin{tabular}{|c|c|c|c|c|c|c|c|c|c|}
\hline \multirow[b]{2}{*}{ UMR Mass } & \multirow{2}{*}{$\begin{array}{r}\text { Mass } \\
\text { HR Mass }\end{array}$} & \multicolumn{2}{|l|}{ Fragment } & \multicolumn{3}{|c|}{ Relative intensity } & \multicolumn{3}{|c|}{ Fraction $(\%)$} \\
\hline & & Ion $^{\mathrm{a}}$ & Parent ion & $\mathrm{CV}^{\mathrm{b}}$ & $S V^{b}$ & SV Lit. ${ }^{c}$ & $\mathrm{CV}^{\mathrm{b}}$ & $\mathrm{SV}^{\mathrm{b}}$ & SV Lit. ${ }^{\mathrm{c}}$ \\
\hline & & & & \multicolumn{3}{|c|}{$\mathrm{NH}_{4} \mathrm{NO}_{3}$} & & & \\
\hline 30 & 29.9980 & $\mathrm{NO}^{+}$ & $\mathrm{NO}^{+}$ & 100.0 & 100.0 & 100.0 & $92.5 \pm 1.1$ & $72.9 \pm 3.8$ & $56.5 \pm 4.6$ \\
\hline 46 & 45.9929 & $\mathrm{NO}_{2}^{+}$ & $\mathrm{NO}_{2}^{+}$ & 7.5 & 34.8 & 74.9 & $6.9 \pm 1.1$ & $25.3 \pm 4.3$ & $42.2 \pm 8.0$ \\
\hline \multirow[t]{2}{*}{63} & 62.9956 & $\mathrm{HNO}_{3}^{+}$ & $\mathrm{HNO}_{3}^{+}$ & 0.1 & 0.9 & 0.9 & $0.1 \pm<0.1$ & $0.1 \pm<0.1$ & $0.5 \pm 0.1$ \\
\hline & & & & \multicolumn{3}{|c|}{$\left(\mathrm{NH}_{4}\right)_{2} \mathrm{SO}_{4}$} & & & \\
\hline 16 & 15.9949 & $\mathrm{O}^{+}$ & $\mathrm{O}^{+}$ & 6.1 & 8.6 & 0.7 & $2.0 \pm 0.2$ & $2.1 \pm 0.6$ & $0.2 \pm<0.1$ \\
\hline 17 & 17.0027 & $\mathrm{HO}^{+}$ & $\mathrm{HO}^{+}$ & 20.8 & 22.9 & 16.8 & $6.9 \pm 0.6$ & $5.7 \pm 0.2$ & $4.2 \pm 0.3$ \\
\hline 18 & 18.0106 & $\mathrm{H}_{2} \mathrm{O}^{+}$ & $\mathrm{H}_{2} \mathrm{O}^{+}$ & 91.1 & 100.0 & 78.2 & $30.2 \pm 0.9$ & $25.0 \pm 0.6$ & $19.8 \pm 1.6$ \\
\hline 24 & 23.9835 & $\mathrm{SO}^{2+}$ & $\mathrm{SO}^{+}$ & 0.5 & 0.6 & 0.6 & $0.2 \pm<0.1$ & $0.1 \pm<0.1$ & $0.2 \pm<0.1$ \\
\hline 32 & 31.9721 & $\mathrm{~S}^{+}$ & $\mathrm{S}^{+}$ & 8.1 & 9.8 & 14.1 & $2.7 \pm 0.3$ & $2.5 \pm 0.8$ & $3.6 \pm 0.1$ \\
\hline 48 & 47.967 & $\mathrm{SO}^{+}$ & $\mathrm{SO}^{+}$ & 60.1 & 78.1 & 67.1 & $19.9 \pm 0.4$ & $19.5 \pm 0.3$ & $17.0 \pm 0.4$ \\
\hline 49 & 48.9748 & $\mathrm{HSO}^{+}$ & $\mathrm{HSO}^{+}$ & $<0.1$ & 0.4 & NA & $<0.1$ & $0.1 \pm<0.1$ & NA \\
\hline 50 & 49.9826 & $\mathrm{H}_{2} \mathrm{SO}^{+}$ & $\mathrm{H}_{2} \mathrm{SO}^{+}$ & $<0.1$ & 0.2 & NA & $<0.1$ & $0.1 \pm<0.1$ & NA \\
\hline 64 & 63.9619 & $\mathrm{SO}_{2}^{+}$ & $\mathrm{SO}_{2}^{+}$ & 100.0 & 85.8 & 100.0 & $33.2 \pm 0.5$ & $21.4 \pm 0.4$ & $25.3 \pm 1.5$ \\
\hline 65 & 64.9613 & $j^{33} \mathrm{SO}_{2}^{+}$ & $\mathrm{SO}_{2}^{+}$ & 0.9 & 0.7 & 5.7 & $0.3 \pm<0.1$ & $0.2 \pm<0.1$ & $1.4 \pm 0.2$ \\
\hline 65 & 64.9697 & $\mathrm{HSO}_{2}^{+}$ & $\mathrm{HSO}_{2}^{+}$ & 0.2 & 6.1 & & $0.1 \pm<0.1$ & $1.5 \pm 0.1$ & \\
\hline 80 & 79.9568 & $\mathrm{SO}_{3}^{+}$ & $\mathrm{SO}_{3}^{+}$ & $<0.1$ & 38.0 & 56.7 & $0.9 \pm<0.1$ & $9.5 \pm 0.1$ & $14.3 \pm 2.2$ \\
\hline 81 & 80.9562 & $j^{33} \mathrm{SO}_{3}^{+}$ & $\mathrm{SO}_{3}^{+}$ & 2.7 & 0.3 & 26.2 & $0.1 \pm<0.1$ & $0.1 \pm<0.1$ & $6.6 \pm 0.5$ \\
\hline 81 & 80.9646 & $\mathrm{HSO}_{3}^{+}$ & $\mathrm{HSO}_{3}^{+}$ & 0.2 & 23.8 & & $0.4 \pm<0.1$ & $5.9 \pm 0.1$ & \\
\hline 82 & 81.9725 & $\mathrm{H}_{2} \mathrm{SO}_{3}^{+}$ & $\mathrm{H}_{2} \mathrm{SO}_{3}^{+}$ & $<0.1$ & 0.3 & NA & $<0.1$ & $0.1 \pm<0.1$ & NA \\
\hline 96 & 95.9517 & $\mathrm{SO}_{4}^{+}$ & $\mathrm{SO}_{4}^{+}$ & $<0.1$ & $<0.1$ & NA & $<0.1$ & $<0.1$ & NA \\
\hline 97 & 96.9418 & $\mathrm{HS}_{2} \mathrm{O}_{2}^{+}$ & $\mathrm{HS}_{2} \mathrm{O}_{2}^{+}$ & $<0.1$ & $<0.1$ & NA & $<0.1$ & $<0.1$ & NA \\
\hline 97 & 96.9596 & $\mathrm{HSO}_{4}^{+}$ & $\mathrm{HSO}_{4}^{+}$ & $<0.1$ & 0.1 & NA & $<0.1$ & $<0.1$ & NA \\
\hline 98 & 97.9674 & $\mathrm{H}_{2} \mathrm{SO}_{4}^{+}$ & $\mathrm{H}_{2} \mathrm{SO}_{4}^{+}$ & 0.1 & 12.6 & 16.7 & $0.3 \pm<0.1$ & $3.1 \pm 0.1$ & $4.2 \pm 0.5$ \\
\hline
\end{tabular}

a All the isotope ions are calculated based on isotope ratios in fragmentation table, thus not shown here, and account for $\sim 1 \%$ of nitrate and $\sim 3 \%$ of sulfate in the SV and $\sim 0.5 \%$ of nitrate and $\sim 3 \%$ in sulfate in the CV. ${ }^{\mathrm{b}}$ From this study. ${ }^{\mathrm{c}}$ From Hogrefe et al. (2004).

SV (0.11-0.38) are indicative of substantial thermal decomposition occurring in the $\mathrm{SV}$, which is even larger in the $\mathrm{CV}$. In the NIST spectra database, standard $70 \mathrm{eV}$ EI of $\mathrm{SO}_{2}(\mathrm{~g})$ and $\mathrm{H}_{2} \mathrm{SO}_{4}\left(\mathrm{~g}\right.$ ) yield $\mathrm{SO}_{2}^{+} / \mathrm{SO}^{+}$of $\sim 2$ and $\sim 1$ respectively (Linstrom and Mallard, 2016). Therefore, a possible explanation for the higher $\mathrm{SO}_{2}^{+} / \mathrm{SO}^{+}$in the $\mathrm{CV}$ is consistent with enhanced thermal decomposition in the $\mathrm{CV}$, which produces more $\mathrm{SO}_{2}(\mathrm{~g})$ than in the $\mathrm{SV}$.

Although the exact ion ratios from each standard species are sensitive to the history and status (e.g. tuning or $T_{\mathrm{V}}$ ) of a specific AMS, and can therefore vary among different AMSs, observations of larger fragments from $\mathrm{NO}_{3}$ and $\mathrm{SO}_{4}$ in the SV (compared to the $\mathrm{CV}$ ) just described were consistent across all experiments over several years and also in other independent studies (Xu et al. 2017).

\subsubsection{Recommended adjustments to the fragmentation table for $\mathrm{H}_{2} \mathrm{O}^{+}$and $\mathrm{S}^{+}$in the $\mathrm{CV}$}

Since the detection of nitrate and sulfate is different in the SV and $\mathrm{CV}$, accurate quantification for the $\mathrm{CV}$ requires the use of an $\mathrm{RIESO}_{4}$ determined with the $\mathrm{CV}$. $\mathrm{RIE}_{\mathrm{SO}_{4}} \sim 1.2$ was found in the SV in this study, the same as the default value in the AMS analysis software. $\mathrm{RIE}_{\mathrm{SO}_{4}}$ in the $\mathrm{CV}$ in this study was $\sim 1.7-2.4$, significantly larger than in the $\mathrm{SV}$, although values as low as 1.1 have been observed in the CV with ACSM (Hu et al., 2017). Sulfate RIE can be influenced by many aspects including detailed ionizer, vapourizer, filament positions and turning of ion optics. Differences in the timescales on which sulfate particles fully vapourize on the $\mathrm{SV}$ and $\mathrm{CV}$, as discussed in Sect. 3.2, could also give rise to differences in the measured $\mathrm{RIE}_{\mathrm{SO}_{4}}$ for different vapourizers.

The fragmentation tables used in the AMS software also need an adjustment for accurate mass quantification, as the contribution of ammonium sulfate to $\mathrm{H}_{2} \mathrm{O}^{+}$and $\mathrm{S}^{+}$are dif- 

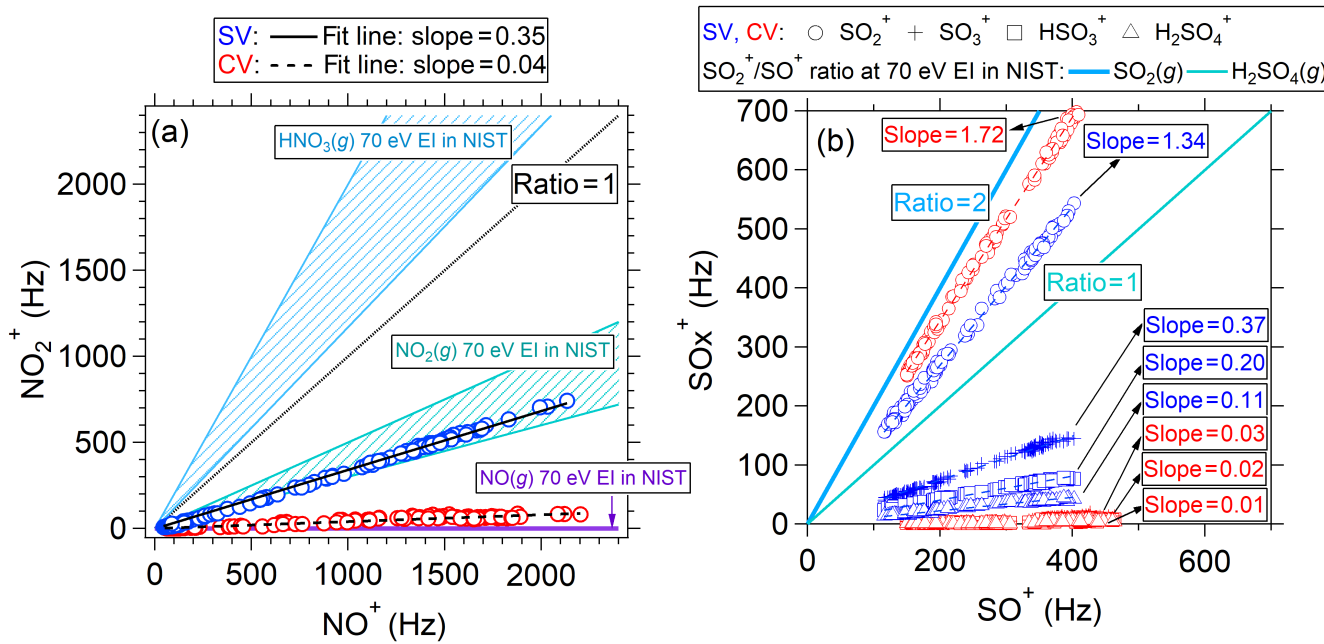

Figure 3. Scatter plots of (a) $\mathrm{NO}_{2}^{+} / \mathrm{NO}^{+}$for $\mathrm{NH}_{4} \mathrm{NO}_{3}$ and (b) $\mathrm{SO}_{x}^{+} / \mathrm{SO}^{+}$for $\left(\mathrm{NH}_{4}\right)_{2} \mathrm{SO}_{4}$ measured with AMS with the $\mathrm{SV}$ and $\mathrm{CV}$. $\mathrm{NO}_{2}^{+} / \mathrm{NO}^{+}$ratios the NIST database for $70 \mathrm{eV}$ EI ionization of $\mathrm{HNO}_{3}(\mathrm{~g}), \mathrm{NO}_{2}(\mathrm{~g})$ and $\mathrm{NO}(\mathrm{g})$ are also shown in $(\mathbf{a}) . \mathrm{SO}_{2}^{+} / \mathrm{SO}^{+}$ratios from NIST for $\mathrm{SO}_{2}(\mathrm{~g})$ and $\mathrm{H}_{2} \mathrm{SO}_{4}(\mathrm{~g})$ are also shown in (b). $\mathrm{SO}_{x}^{+}$ions include $\mathrm{SO}_{2}^{+}, \mathrm{SO}_{3}^{+}, \mathrm{HSO}_{3}^{+}$and $\mathrm{H}_{2} \mathrm{SO}_{4}^{+}$.

Table 2. Changes of the fragmentation table for the AMS data analysis software, modified for the CV based on $\left(\mathrm{NH}_{4}\right)_{2} \mathrm{SO}_{4}$ measurement in pure argon gas. The default settings in the analysis software for SV are also shown. These ratios should be implemented in both UMR and HR fragmentation tables.

\begin{tabular}{|c|c|c|c|}
\hline \multirow[t]{2}{*}{$m / z /$ ion } & \multirow[t]{2}{*}{ Frag_sulfate } & \multicolumn{2}{|c|}{ Frag__SO 3} \\
\hline & & SV (default) & $\mathrm{CV}$ \\
\hline $18 / \mathrm{H}_{2} \mathrm{O}^{+}$ & Frag_SO ${ }_{3}[18]$ & $0.67 * \mathrm{frag}_{-} \mathrm{SO}_{3}[64], 0.67 * \mathrm{frag}_{-} \mathrm{SO}_{3}[48]$ & $0.56 *$ frag_SO$_{3} \mathrm{SO}_{3}[64], 0.56 * \mathrm{frag}_{-} \mathrm{SO}_{3}[48]$ \\
\hline $32 / \mathrm{S}^{+}$ & Frag_SO ${ }_{3}[18]$, Frag_H ${ }_{2} \mathrm{SO}_{4}[32]$ & $0.21 *$ frag_SO$_{3}[64], 0.21 * \mathrm{frag}_{-} \mathrm{SO}_{3}[48]$ & $0.05 *$ frag__SO$_{3}[64], 0.05 * \mathrm{frag}_{-} \mathrm{SO}_{3}[48]$ \\
\hline
\end{tabular}

ferent for the CV. The changes in the fragmentation table for the $\mathrm{CV}$ is shown in Table 2 based on the fragmentation pattern obtained in Table 1. These modifications need to be made for both the UMR and HR fragmentation tables. We note that the determination of sulfate and nitrate in mixed inorganic/organic aerosols (e.g. ambient air) includes subtraction of organic interferences at several $\mathrm{m} / \mathrm{z}$ associated with inorganic ions (Allan et al., 2004b). It is expected that some fragmentation table entries that affect sulfate quantification (in particular frag_SO $\mathrm{SO}_{3}[48]$ and [64]) will need revision for an accurate quantification of mixed aerosols from UMR data. Higher coefficients for $\mathrm{H}_{2} \mathrm{O}^{+}$and $\mathrm{S}^{+}$ions generated from $\mathrm{SO}_{4}$ were reported by Xu et al. (2017). The reason for the difference may be due to typical variations between instruments that have been observed before. However, since RIE calibrations utilize the fragmentation waves, these differences will be effectively accounted for in the RIE calibrations with $\mathrm{SO}_{4}$ and thus do not affect the quantification of $\mathrm{SO}_{4}$ if such a calibration is performed. These differences also suggest that fragmentation for the $\mathrm{CV}$ should continue to be investigated in future studies. We also note that the corrections can vary depending on the type of organics sampled, especially in laboratory and source studies, and thus individual users should always examine those corrections for specific experiments and modify them if needed.

\subsubsection{Effect of $T_{\mathrm{v}}$}

$T_{\mathrm{v}}$ can substantially impact vapourization and thermal decomposition, and hence the fragmentation patterns as well as quantification in the AMS (Canagaratna et al., 2015; Docherty et al., 2015). The $T_{\mathrm{v}}$-dependent fragmentation patterns can help to understand the detection process for both vapourizers, and also help to determine the optimum $T_{\mathrm{v}}$ for the $\mathrm{CV}$. In this study, fragmentation patterns of four inorganic standards $\left(\mathrm{NH}_{4} \mathrm{NO}_{3}, \mathrm{NaNO}_{3},\left(\mathrm{NH}_{4}\right)_{2} \mathrm{SO}_{4}\right.$, and $\left.\mathrm{NH}_{4} \mathrm{Cl}\right)$ over the entire usable range of $T_{\mathrm{v}}\left(200-800^{\circ} \mathrm{C}\right)$ in both the SV and $\mathrm{CV}$ are explored (Fig. 4).

\section{$\mathrm{NH}_{4} \mathrm{NO}_{3}$}

In the $\mathrm{SV}, \mathrm{NO}_{2}^{+} / \mathrm{NO}^{+}$from $\mathrm{NH}_{4} \mathrm{NO}_{3}$ decreased by $\sim 40 \%$ while $T_{\mathrm{v}}$ increased from 200 to $750^{\circ} \mathrm{C}$ (Fig. 4a). A possible explanation for this decreasing trend is that higher $T_{\mathrm{v}}$ increases the fraction of the nitrate that thermally decomposes into smaller molecules. For the $\mathrm{CV}, \mathrm{NO}_{2}^{+} / \mathrm{NO}^{+}$varied within a small range, and was an order of magnitude 

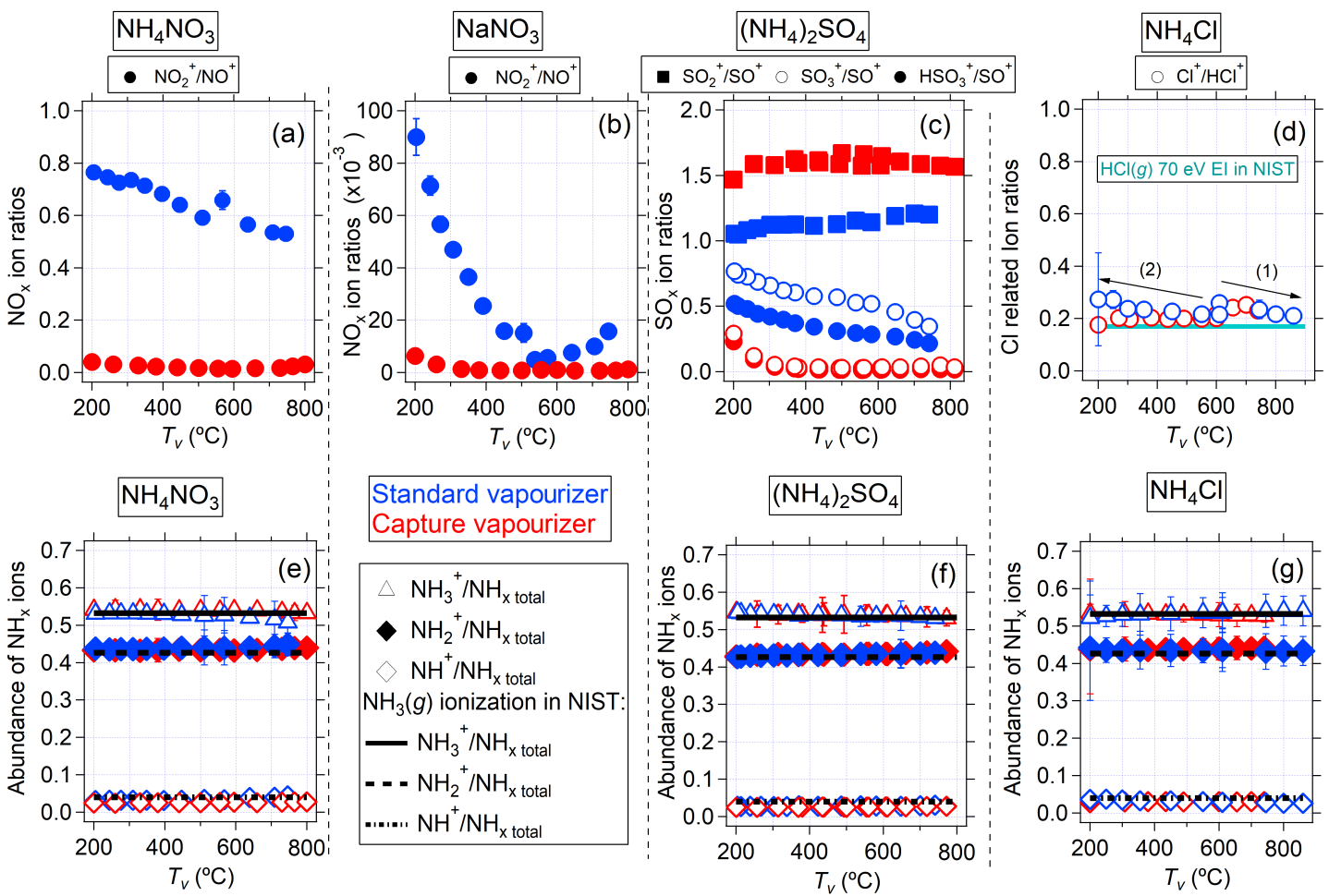

Figure 4. Ion ratios of pure inorganic standard species vs. $T_{\mathrm{v}}$ for the $\mathrm{SV}$ and $\mathrm{CV}$ : (a) and (e) $\mathrm{NH}_{4} \mathrm{NO}_{3}$, (b) $\mathrm{NaNO}_{3}$, (c) and (f) $\left(\mathrm{NH}_{4}\right)_{2} \mathrm{SO}_{4}$, and (d) and (g) $\mathrm{NH}_{4} \mathrm{Cl}$. Error bars are standard deviations. For the $\mathrm{NH}_{4} \mathrm{Cl}$ experiment, we first increased $T_{\mathrm{V}}$ from $600^{\circ} \mathrm{C}$ (arrow labelled 1) in both the $\mathrm{SV}$ and $\mathrm{CV}$, then turned it back to $600^{\circ} \mathrm{C}$, and decreased the $T_{\mathrm{V}}$ to $200^{\circ} \mathrm{C}$ (arrow 2).

lower (0.015-0.04) than for the SV, as discussed above. $\mathrm{NO}_{2}^{+} / \mathrm{NO}^{+}$in the $\mathrm{CV}$ at $T_{\mathrm{V}}=200^{\circ} \mathrm{C}(0.04)$ was much lower than in $\mathrm{SV}$ at $T_{\mathrm{v}}=750^{\circ} \mathrm{C}(0.5)$, suggesting the thermal decomposition was stronger in the CV even at low $T_{\mathrm{v}}$ due to the increased vapour collisions and residence time.

\section{$\mathrm{NaNO}_{3}$}

$\mathrm{NaNO}_{3}$ is less volatile than $\mathrm{NH}_{4} \mathrm{NO}_{3}$ with melting and boiling points of 306 and $380^{\circ} \mathrm{C}$ respectively, substantially higher than for $\mathrm{NH}_{4} \mathrm{NO}_{3}$ (melting point of $169^{\circ}$ and boiling point of $\sim 210^{\circ}$; Haynes, 2015). Since boiling points are referenced to $1 \mathrm{~atm}$, these species will boil at lower temperatures under the vacuum of the AMS vapourizer. Here we are using the boiling points as indicators of relative volatility of different species. In the $\mathrm{SV}, \mathrm{NO}_{2}^{+} / \mathrm{NO}^{+}$ratio for $\mathrm{NaNO}_{3}$ ranged from 0.1 at $200^{\circ} \mathrm{C}$ and 0.005 at $550^{\circ} \mathrm{C}$, which is 10 100 times lower than typical values from $\mathrm{NH}_{4} \mathrm{NO}_{3}(0.29$ 0.75) (Fig. 4b). Much lower $\mathrm{NO}_{2}^{+} / \mathrm{NO}^{+}$from $\mathrm{NaNO}_{3}$ compared to $\mathrm{NH}_{4} \mathrm{NO}_{3}$ at $T_{\mathrm{v}}=600^{\circ} \mathrm{C}$ have also been reported in prior studies with SV in AMS (Bruns et al., 2010). A greater thermal decomposition due to a longer residence time of the particles on the vapourizer surface (resulting from slower vapourization) for $\mathrm{NaNO}_{3}$ than $\mathrm{NH}_{4} \mathrm{NO}_{3}$ and different thermal decomposition pathways (as $\mathrm{NaNO}_{3}$ cannot produce $\left.\mathrm{HNO}_{3}(\mathrm{~g})\right)$ are two possible explanations. In the $\mathrm{CV}$, much lower $\mathrm{NO}_{2}^{+} / \mathrm{NO}^{+}$ratios for $\mathrm{NaNO}_{3}(0.001-0.006)$ were observed compared to those from the SV (0.005-0.1), consistent with the results for $\mathrm{NH}_{4} \mathrm{NO}_{3}$.

\section{$\left(\mathrm{NH}_{4}\right)_{2} \mathrm{SO}_{4}$}

Some $T_{\mathrm{v}}$-dependent changes of $\mathrm{SO}_{x}^{+} / \mathrm{SO}^{+}$ratios were observed for both vapourizers (Fig. $4 \mathrm{c}$ ). As $T_{\mathrm{v}}$ increased, the relative abundance of the heavier ions $\left(\mathrm{HSO}_{3}^{+}\right.$and $\mathrm{SO}_{3}^{+}$) decreased and $\mathrm{SO}_{2}^{+}$increased, consistent with increasing thermal decomposition of $\left(\mathrm{NH}_{4}\right)_{2} \mathrm{SO}_{4}$ with more abundant $\mathrm{SO}_{2}(\mathrm{~g})$ and lower $\mathrm{H}_{2} \mathrm{SO}_{4}(\mathrm{~g})$ in the thermal decomposition products. In contrast to the continuous variation of $\mathrm{SO}_{x}^{+} / \mathrm{SO}^{+}$ratios in the $\mathrm{SV}$ over the entire $T_{\mathrm{v}}$ range, the $\mathrm{CV}$ only showed a change of $\mathrm{SO}_{x}^{+} / \mathrm{SO}^{+}$below $T_{\mathrm{v}}=300^{\circ} \mathrm{C}$ and then levelled off. This indicates that the thermal decomposition process of already vapourized sulfate (within severalsecond timescale of MS mode) is complete in the $\mathrm{CV}$ at $T_{\mathrm{v}}>300^{\circ} \mathrm{C}$.

\section{$\mathrm{NH}_{4} \mathrm{Cl}$}

The thermal decomposition of $\mathrm{NH}_{4} \mathrm{Cl}$ particles is expected to occur through the reaction (Zhu et al., 2007) $\mathrm{NH}_{4} \mathrm{Cl}(\mathrm{s}) \rightarrow \mathrm{NH}_{3}(\mathrm{~g})+\mathrm{HCl}(\mathrm{g})$. The main fragments from chloride in the AMS are $\mathrm{HCl}^{+}$and $\mathrm{Cl}^{+}$(Allan et al., 
2004b). In this study, $\mathrm{Cl}^{+} / \mathrm{HCl}^{+}$vs. $T_{\mathrm{v}}$ from both vapourizers are within a narrow range $(0.17-0.27)$, which is similar to the $70 \mathrm{eV}$ EI fragmentation pattern of $\mathrm{HCl}(\mathrm{g})$ in the NIST database $\left(\mathrm{Cl}^{+} / \mathrm{HCl}^{+}=\sim 0.17\right.$; Linstrom and Mallard, 2016) and also consistent with the $\mathrm{Cl}^{+} / \mathrm{HCl}^{+}$ratio observed in other ambient data sets $(0.175-0.24)$ (Hu et al., 2016). Compared to much larger changes for $\mathrm{NO}_{3}$ and $\mathrm{SO}_{4}$ fragment ion ratios, the differences in $\mathrm{HCl}^{+} / \mathrm{Cl}^{+}$ratio between the vapourizers and temperatures are relatively small. This suggests, for $\mathrm{Cl}^{+}$and $\mathrm{HCl}^{+}$, that the thermal decomposition and ionization fragmentation of $\mathrm{NH}_{4} \mathrm{Cl}$ particles are similar for both vapourizers across different temperatures, and likely mainly produced from direct ionization of $\mathrm{HCl}(\mathrm{g})$. We note that unlike $\mathrm{NO}_{3}$ or $\mathrm{SO}_{4}, \mathrm{HCl}(\mathrm{g})$ does not have a thermal decomposition pathway.

The small variations of $\mathrm{Cl}^{+} / \mathrm{HCl}^{+}$vs. $T_{\mathrm{v}}$ may have been due to the changing background of $\mathrm{Cl}^{+}$and $\mathrm{HCl}^{+}$ due to the different stickiness of chloride decomposition products on the vapourizer surface and ionization chamber walls. Drewnick et al. (2015) reported that $\mathrm{Cl}^{+}$had a slowly evolving background signal ( 8 to $>30 \mathrm{~min}$ at $T_{\mathrm{V}} \sim 600-$ $720^{\circ} \mathrm{C}$ ). We evaluated this effect by examining $\mathrm{Cl}^{+} / \mathrm{HCl}^{+}$ at the same $T_{\mathrm{v}}\left(\sim 600^{\circ} \mathrm{C}\right)$ after increasing $T_{\mathrm{v}}$ from $\sim 600$ to $850^{\circ} \mathrm{C}$, and then returning to $600^{\circ} \mathrm{C}$. We found that $\mathrm{Cl}^{+} / \mathrm{HCl}^{+}$decreased by $25 \%$ in the $\mathrm{SV}$ and by $5 \%$ in the $\mathrm{CV}$ compared to the values before $T_{\mathrm{v}}$ was changed (Fig. 4d). This hysteresis behaviour supports the assumption that changes in the slowly evaporating signals were likely the main reason for the observed variations of $\mathrm{Cl}^{+} / \mathrm{HCl}^{+}$ratios at different $T_{\mathrm{v}}$.

Drewnick et al. (2015) suggested that tungsten oxide chloride $\left(\mathrm{WO}_{2} \mathrm{Cl}_{2}(\mathrm{~g})\right)$ is detected in AMS spectra from the interaction between sampled chloride aerosol species and vapourizer surfaces, although signal levels are very small, e.g. $0.04 \%$ of the total $\mathrm{NH}_{4} \mathrm{Cl}$ signal. In this study, some ions that were consistent with $\mathrm{WO}_{2} \mathrm{Cl}_{2}$ signals, namely $\mathrm{WCl}^{+}$ and $\mathrm{WO}_{2}^{+}$, were also observed when sampling $\mathrm{NH}_{4} \mathrm{Cl}$ with $\mathrm{SV}$. The abundance of those ions was very low $(<0.02 \%)$, similar to observations by Drewnick et al. (2015). Jimenez et al. (2003) reported $\mathrm{MoO}^{+}$and $\mathrm{MoO}_{2}^{+}$when sampling iodineoxides with a prototype AMS vapourizer made of molybdenum. Following that work, we searched for the $\mathrm{MoO}^{+}$, $\mathrm{MoO}_{2}^{+}$and $\mathrm{MoCl}^{+}$signals in the $\mathrm{CV}$, but saw no detectable enhancement of either ion when sampling $\mathrm{NH}_{4} \mathrm{Cl}$ and other inorganic species in this study.

\section{$\mathrm{NH}_{4}$ ions from $\mathrm{NH}_{4} \mathrm{NO}_{3},\left(\mathrm{NH}_{4}\right)_{2} \mathrm{SO}_{4}$ and $\mathrm{NH}_{4} \mathrm{Cl}$}

The abundance of $\mathrm{NH}_{x}^{+}$ions $\left(\mathrm{NH}_{x}^{+}=\mathrm{NH}^{+}+\mathrm{NH}_{2}^{+}+\mathrm{NH}_{3}^{+}\right)$ from three $\mathrm{NH}_{4}$-containing species $\left(\mathrm{NH}_{4} \mathrm{NO}_{3},\left(\mathrm{NH}_{4}\right)_{2} \mathrm{SO}_{4}\right.$ and $\mathrm{NH}_{4} \mathrm{Cl}$ ) vs. $T_{\mathrm{v}}$ is shown in Fig. $4 \mathrm{e}-\mathrm{f}$. The fragmentation patterns of $\mathrm{NH}_{4}$ across the different vapourizers and compounds were very similar. The fragmentation pattern of $\mathrm{NH}_{4}$ in AMS was very consistent with the standard patterns of $\mathrm{NH}_{3}$ (g) for $70 \mathrm{eV}$ EI in the NIST database (Fig. 4e-f; Lin- strom and Mallard, 2016). A stable fragmentation pattern of $\mathrm{NH}_{4}$ as a function of $T_{\mathrm{v}}$ (with variations of those abundances smaller than $4 \%$ ) also suggests that thermal decomposition played a very minor role after $\mathrm{NH}_{3}(\mathrm{~g})$ vapourization.

\subsubsection{Effect of particle beam position on the vapourizer}

A key component of the AMS is an aerodynamic lens that focuses particles into a very narrow beam that is focused onto the centre of the vapourizer (Liu et al., 1995a, b; Jayne et al., 2000). The alignment of the particle beam with the vapourizer centre (typically referred to as a "lens alignment") is checked regularly, as a misalignment can lead to particle losses and underestimation of particle concentrations. Lens alignment is usually performed with $300 \mathrm{~nm}$ pure $\mathrm{NH}_{4} \mathrm{NO}_{3}$ particles, since these particles are known to be easily focused ( $\sim 0.5 \mathrm{~mm}$ beam diameter at the vapourizer) and a CPC is used to verify stable particle concentration during sampling (typically within 5\% during an experiment). The lens position is varied (first horizontally and later vertically, or vice versa), and the edges of vapourizer can be identified by a steep variation in aerosol signal. A microcalliper is used to read the lens position during this experiment. In a CV AMS, lens alignment requires greater precision, since the entrance of the vapourizer is narrower than for SV (Fig. 1a). Lens alignment effects on signal intensity, fragmentation patterns, and size distributions of $\mathrm{NH}_{4} \mathrm{NO}_{3}$ for both vapourizers are discussed below. Since the cross section of the vapourizer is radially symmetrical, lens alignment results from horizontal and vertical movements are generally very similar. Hence, only data from the horizontal dimension are shown (Figs. 56).

For these experiments, the lens was first aligned such that the particle beam almost missed the vapourizer on the left side and a low $\mathrm{NO}_{3}$ signal was observed. Then the particle beam was moved stepwise toward the edge of the vapourizer, which was identified by the sharp increase of $\mathrm{NO}_{3}$ signal, then to the centre of vapourizer and finally to the other edge. For both vapourizers, the $\mathrm{NO}_{3}$ signal shows a symmetrical variation with a broad plateau in the centre (Figs. 56). In the $\mathrm{CV}$, low $\mathrm{NO}_{2}^{+} / \mathrm{NO}^{+}(\sim 0.07)$ is observed in the vapourizer centre as previously discussed (Fig. 3a). However, a much higher $\mathrm{NO}_{2}^{+} / \mathrm{NO}^{+}$ratio $(0.6-0.8)$ was observed at the edges of the vapourizer (Fig. 5). These values are similar to those observed for the centre of the SV (0.2-0.7). The higher $\mathrm{NO}_{2}^{+} / \mathrm{NO}^{+}$ratios on the edges of the $\mathrm{CV}$ are consistent with the results of Xu et al. (2017). This is likely caused by the lack of wall collisions for vapour molecules inside of the $\mathrm{CV}$ when the particle beam hits the $\mathrm{CV}$ edge. The edge position is illustrated in Fig. 1a. This enhanced $\mathrm{NO}_{2}^{+}$ion signal on the edge of vapourizer can also be used to determine the centre of the lens alignment. When the beam is off the outside edge of the vapourizer assembly, a small signal can still be observed since the particles impact on another surface 


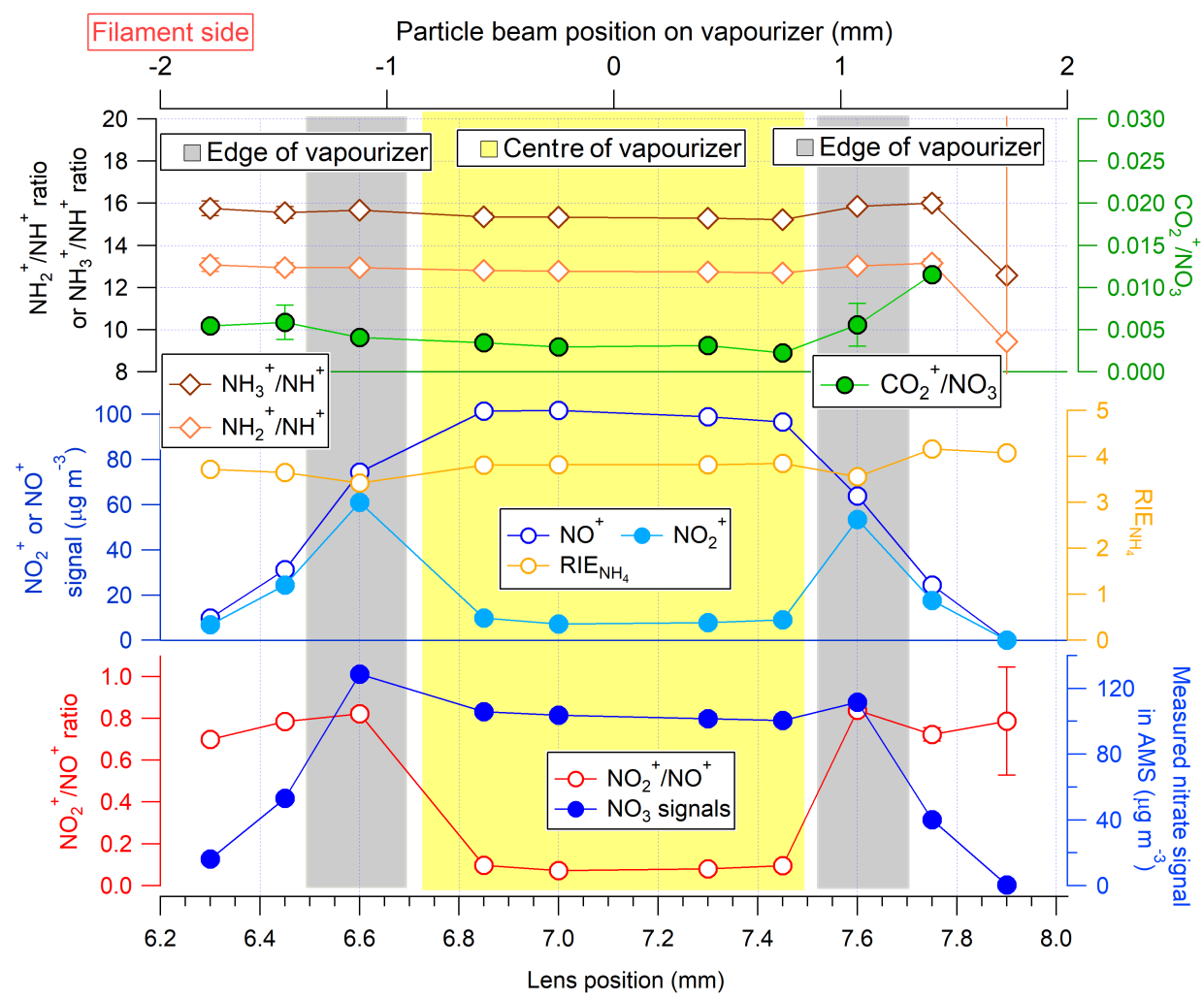

Figure 5. $\mathrm{CV}$ : particle beam position dependence of $\mathrm{NO}_{2}^{+} / \mathrm{NO}^{+}$, total detected nitrate, $\mathrm{NO}_{2}^{+}$and $\mathrm{NO}^{+}$signals, $\mathrm{RIE}_{\mathrm{NH}}, \mathrm{NH}_{2}^{+} / \mathrm{NH}^{+}$, $\mathrm{NH}_{3}^{+} / \mathrm{NH}^{+}$and nitrate equivalent mass ratio of $\mathrm{CO}_{2}^{+} / \mathrm{NO}_{3}$. The shaded areas are a rough indication for where the particle beam hits the vapourizer. A constant IE obtained with pure $\mathrm{NH}_{4} \mathrm{NO}_{3}$ particles at the centre of the lens was applied to all data collected in this experiment. The error bars are the variabilities (standard deviation) for each point. Some error bars cannot be seen in this figure because their values are very small. The particle size-resolved detection for the edge and centre positions are shown in Fig. 7.

(the vapourizer mount) just outside of the ionization chamber.

In the $\mathrm{CV}$, the total nitrate signal also showed two peaks at the edge positions, 10-20\% higher than at the centre. The slightly higher $\mathrm{NO}_{3}$ signal at the edge of the $\mathrm{CV}$ may be due to (1) a higher $\mathrm{IE}_{\mathrm{NO}_{3}}$ resulting from the different spatial distribution of vapour molecules, which may better overlap the electron beam and/or ion extraction regions; (2) a higher $\mathrm{IE}_{\mathrm{NO}_{3}}$ due to longer residence time of the molecules in the electron beam due to the lower vapour molecule velocity resulting from the lower temperature at the front end of the $\mathrm{CV}$ or (3) a different RIE of the particle vapour resulting from a change in thermal decomposition products on the vapourizer. For example, at the edge the $\mathrm{HNO}_{3}(\mathrm{~g})$ fraction may be higher than at the centre. $\mathrm{HNO}_{3}(\mathrm{~g})$ has a higher cross section than $\mathrm{NO}_{2}(\mathrm{~g})$ and $\mathrm{NO}(\mathrm{g})$ due to its higher molar weight (and possibly a lower velocity). Thus it may result in more ions being formed. The higher $\mathrm{NO}_{3}$ signal on the left edge than on the right edge may be due to the right side being closer to the heated filament that supplies electrons for the ionization process, thus resulting in slightly larger overlap with the electron cloud and increasing ionization efficiency. Support- ing this hypothesis, equal enhancement of $\mathrm{NO}_{3}$ signal on the edges was observed for lens alignment in the vertical direction (not shown). In the SV, we did not observe this enhanced nitrate signal on the vapourizer edge (Fig. 6), which is consistent with the smaller difference in $\mathrm{NO}_{2}^{+} / \mathrm{NO}^{+}$between the vapourizer centre and edge, and the fact that hitting the centre as opposed to the edge of the SV is not expected to greatly change the number of vapour-wall collisions. The reason for the slightly increasing trend of $\mathrm{NO}_{2}^{+} / \mathrm{NO}^{+}$ratios toward the filament side in Fig. 6 is unclear.

In contrast to the variable $\mathrm{NO}_{2}^{+} / \mathrm{NO}^{+}, \mathrm{NH}_{2}^{+} / \mathrm{NH}^{+}$and $\mathrm{NH}_{3}^{+} / \mathrm{NH}^{+}$from $\mathrm{NH}_{4}$ did not show systematic differences between the centre and the edge of both vapourizers. The constant ratios support direct EI ionization on $\mathrm{NH}_{3}(\mathrm{~g})$ as discussed above. Slightly lower $\mathrm{RIE}_{\mathrm{NH}_{4}}$ are observed at the edges of the $\mathrm{CV}$, which might be due to changes in the mixture of vapour species formed from nitrate $\left(\mathrm{HNO}_{3}(\mathrm{~g})\right.$, $\mathrm{NO}_{2}(\mathrm{~g})$ and $\mathrm{NO}(\mathrm{g})$ ), while the vapour formed from $\mathrm{NH}_{4}$ stays the same $\left(\mathrm{NH}_{3}(\mathrm{~g})\right)$. In the $\mathrm{SV}$, we did not find systematic differences of $\mathrm{RIE}_{\mathrm{NH}_{4}}$ between the centre and edges, within their higher uncertainties (Fig. 6). 


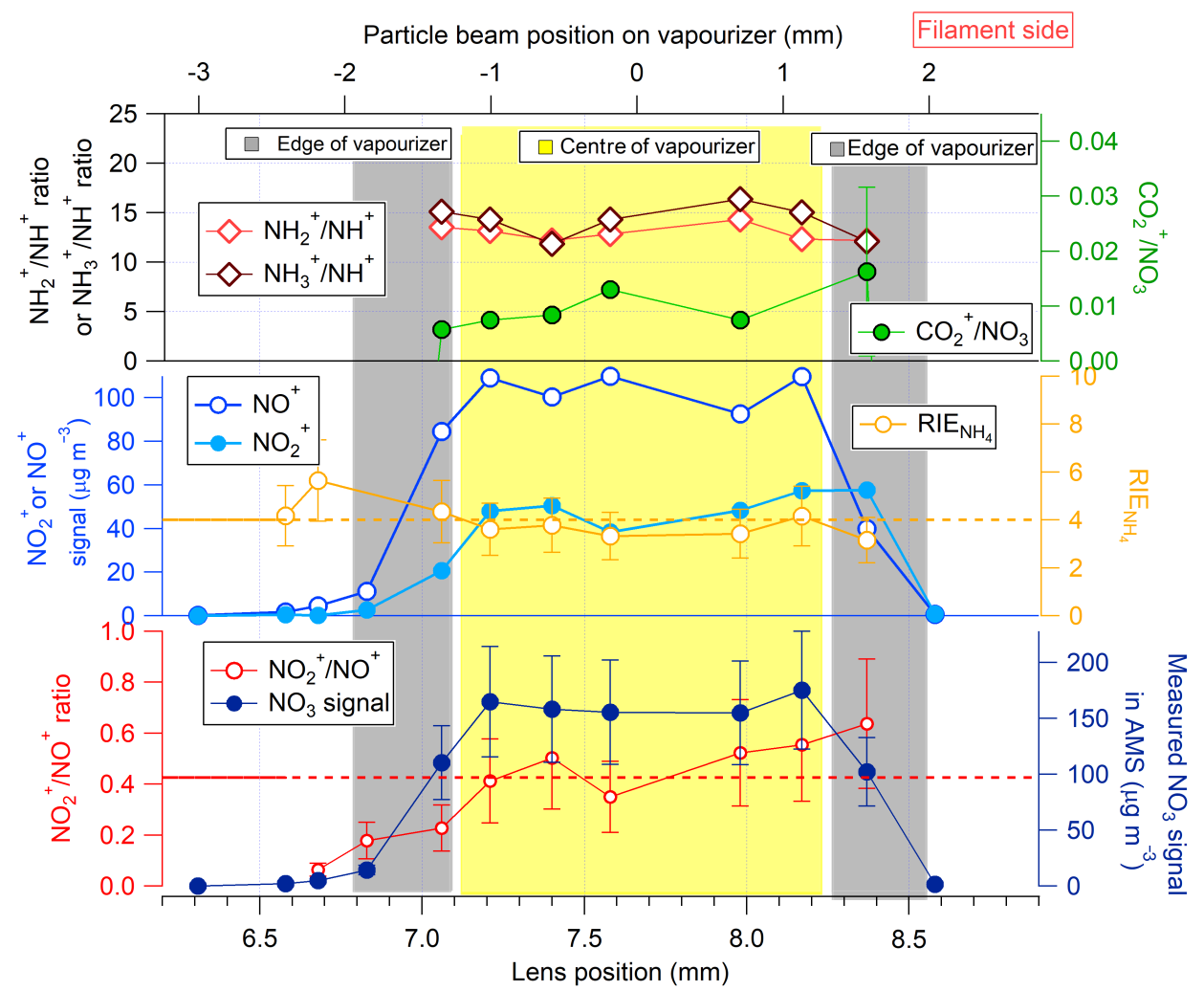

Figure 6. $\mathrm{SV}$ : particle beam position dependence of $\mathrm{NO}_{2}^{+} / \mathrm{NO}^{+}$, total nitrate, $\mathrm{NO}_{2}^{+}$and $\mathrm{NO}^{+}$signals, $\mathrm{RIE}_{\mathrm{NH}_{4}}, \mathrm{NH}_{2}^{+} / \mathrm{NH}^{+}, \mathrm{NH}_{3}^{+} / \mathrm{NH}^{+}$ and nitrate equivalent mass ratio of $\mathrm{CO}_{2}^{+} / \mathrm{NO}_{3}$. The shaded areas are a rough indication of where the particle beam hits the vapourizer. A constant IE obtained with pure $\mathrm{NH}_{4} \mathrm{NO}_{3}$ particles at the centre of the lens was applied to all data collected in this experiment. The error bars represent the measurement variability (standard deviation) for each point. If only one data point for one position was obtained, the error bar for that point was estimated by averaging those from nearby positions. The particle size-resolved detection for the edge and centre positions are shown in Fig. 7. This experiment was performed in a Q-AMS due to limitations in instrument availability and led to lower signal-to-noise ratios than when using a ToF-AMS, which was used in the rest of this paper.

The size-resolved detection of $\mathrm{NO}_{2}^{+}, \mathrm{NO}^{+}, \mathrm{NH}_{2}^{+}$and $\mathrm{NH}_{3}^{+}$ at the edge and centre of both vapourizers is shown in Fig. 7, and was achieved by using PToF acquisition mode in the AMS. The PToFs are the sum of particle travel time and time vapourization and detection. In these experiments particles of $300 \mathrm{~nm} \mathrm{NH} \mathrm{NO}_{3}$ were size selected using a DMA. When directing the particle beam onto the edge of the $\mathrm{CV}$, all ions peaked at the same time (Fig. 7a), but when the beam was directed towards the centre the rise time of different ions was in the order $\mathrm{NO}_{2}^{+}<\mathrm{NH}_{2}^{+} / \mathrm{NH}_{3}^{+}<\mathrm{NO}^{+}$(Fig. 7b). The different rise time likely reflects the increasing residence time of each precursor vapour in the CV cavity, presumably due to increasingly strong interactions with the surface. The same qualitative trend can in fact be observed for tails in the SV in Figs. $7 \mathrm{c}$ and 12a. The peak time when the particle beam hits the centre of the CV is $200 \mu$ s or more later than when hitting the $\mathrm{CV}$ edge. This delay represents a rough desorption and escape time for vapours from the CV cavity. In the SV, consistent peak times were observed at all vapourizer target positions, indicating that the delayed peak time at the cen- tre of the CV is due to trapping in the cavity. The measured PToF time distributions when impacting the edge of the CV are as narrow as those from the SV. Thus, changing the lens alignment to focus particles on the $\mathrm{CV}$ edge can be used to obtain higher-resolution size distributions in the $\mathrm{CV}$ for more volatile species, although presumably with degraded quantification of the total concentration.

\subsubsection{Production of $\mathrm{CO}_{2}^{+}$from inorganic species}

Pieber et al. (2016) have recently shown that $\mathrm{CO}_{2}^{+}$can be produced on the surface of the SV while sampling inorganic particles, presumably from the oxidation/decomposition and release of vapours from residual carbonaceous material on the vapourizer. This causes an interference in the quantification of organic species, which needs to be corrected by adjustments to the fragmentation table using experimental results for an individual AMS instrument (e.g. the measured $\mathrm{CO}_{2}^{+} / \mathrm{NO}_{3}$ ratio during IE calibrations with $\mathrm{NH}_{4} \mathrm{NO}_{3}$ ). The reported mass ratio (nitrate equivalent mass, i.e. using $\mathrm{RIE}=1$ ) of the $\mathrm{CO}_{2}^{+}$produced vs. the inorganic an- 

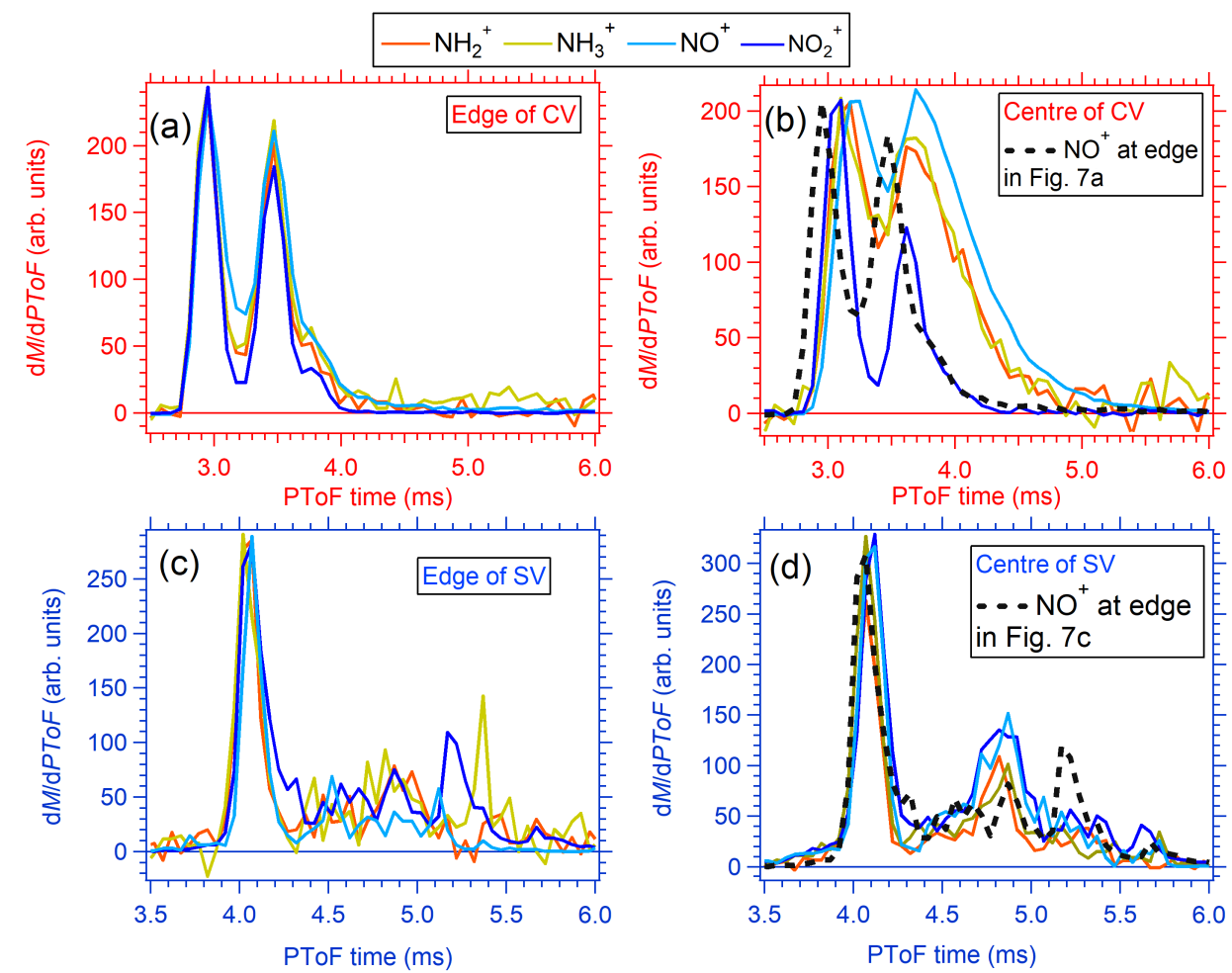

Figure 7. Size-resolved detection of $\mathrm{NH}_{4} \mathrm{NO}_{3}$ (DMA selected $300 \mathrm{~nm}$ particles, including some larger doubly charged particles ) major ions using the PToF acquisition mode at (a) the CV edge (position $=7.6 \mathrm{~mm}$ in Fig. 5), (b) the CV centre (position $=7.1 \mathrm{~mm}$ in Fig. 5), (c) SV edge (position $=8.4 \mathrm{~mm}$ in Fig. 6) and SV centre (position $=7.9 \mathrm{~mm}$ in Fig. 6). All the peaks were normalized to the $\mathrm{NO}^{+}$maximum. Note that the size distributions of the particles were identical within each panel, and that the differences observed between the different ions are due to vapourization and other effects. (see main text). The experiments for the SV and CV were performed at different times, and the fraction of doubly charged particles was lower for the SV experiment.

ion followed the order $\left(\mathrm{NH}_{4}\right)_{2} \mathrm{SO}_{4}(0.1-0.3 \%)<\mathrm{NH}_{4} \mathrm{NO}_{3}$ $(\sim 1 \%)<\mathrm{NaNO}_{3}(3-11 \%)$. Here we investigate this issue for the $\mathrm{CV}$.

The $\mathrm{CO}_{2}^{+}$signal observed when sampling $\mathrm{NH}_{4} \mathrm{NO}_{3}$ in both vapourizers is shown in Fig. 8a. The data were obtained after 4 days of exposing both AMSs $\left(T_{\mathrm{v}}=500-600^{\circ} \mathrm{C}\right)$ to $10-1000 \mu \mathrm{g} \mathrm{m}^{-3}$ of SOA generated during the chamber experiments, which could enhance this interference. Similarly to Pieber et al. (2016), a $\mathrm{CO}_{2}^{+} /$nitrate mass ratio ( $\mathrm{RIE}=1$ were applied to both) of $1.5 \%$ was observed for the SV $\left(0.7 \%\right.$ before exposure). In contrast, negligible $\mathrm{CO}_{2}^{+}$was observed for the $\mathrm{CV}$. We further investigated this effect as a function of $T_{\mathrm{v}}\left(200-800^{\circ} \mathrm{C}\right.$; Fig. 8b). Negligible $\mathrm{CO}_{2}^{+}$ $\left(\mathrm{CO}_{2}^{+} /\right.$nitrate $\left.<0.4 \%\right)$ was observed for the $\mathrm{CV}$ over the entire $T_{\mathrm{V}}$ range, whereas in the $\mathrm{SV}$, ratios of $\sim 1.2 \%$ were observed below $450{ }^{\circ} \mathrm{C}$ and increased ratios up to $3 \%$ were observed at $700-750{ }^{\circ} \mathrm{C}$. The negligible $\mathrm{CO}_{2}^{+}$formation from $\mathrm{NH}_{4} \mathrm{NO}_{3}$ in the $\mathrm{CV}$ may be due to the difference in thermal decomposition pathways between the CV and SV. As discussed above, the main product of nitrate in the CV is likely $\mathrm{NO}(\mathrm{g})$, which is not an efficient oxidizer compared to $\mathrm{NO}_{2}(\mathrm{~g})$. The difference in the vapourizer materials might also play a critical role, as molybdenum is more inert than tungsten (Xu et al., 2017) and may highlight the different catalytic properties of the metals. $\mathrm{CO}_{2}^{+} / \mathrm{NO}_{3}$ ratios that are dependent on lens alignment are shown in Figs. 5-6. No dependence of $\mathrm{CO}_{2}^{+} / \mathrm{NO}_{3}$ ratios in the $\mathrm{SV}$ with lens alignment was found (Fig. 6). However, in the $\mathrm{CV}$, the $\mathrm{CO}_{2}^{+} / \mathrm{NO}_{3}$ ratios are a little higher at the vapourizer edge (Fig. 5), which is consistent with high $\mathrm{NO}_{2}^{+} / \mathrm{NO}^{+}$ratio there.

However, when sampling $\mathrm{NaNO}_{3}$ particles, $\mathrm{CO}_{2}^{+}$formation was observed in the CV (Fig. 8b). Two experiments were conducted, one with a "cleaner" CV (sampling little to no organic aerosols for days) and the other ("dirty") was done the day after exposing the $\mathrm{CV}$ to $10-1000 \mu \mathrm{g} \mathrm{m}^{-3}$ of SOA from chamber studies for four days (dirty $\mathrm{CV}$ ). For the cleaner $\mathrm{CV}, \mathrm{CO}_{2}^{+} /$nitrate for $\mathrm{NaNO}_{3}(0.3-1.2 \%)$ was lower than for SV $(1.2-12 \%)$, especially below $400^{\circ} \mathrm{C}$. For the dirty condition, high ratios were observed above $500^{\circ} \mathrm{C}$ for the $\mathrm{CV}$ (4-11\%) and above $700^{\circ} \mathrm{C}$ for the SV (4-9\%). The fundamental reason for $\mathrm{CO}_{2}^{+}$artefact in the $\mathrm{CV}$ from $\mathrm{NaNO}_{3}$ (but not $\mathrm{NH}_{4} \mathrm{NO}_{3}$ ) is not clear. Higher $\mathrm{CO}_{2}^{+} / \mathrm{NO}_{3}$ ratios when sampling $\mathrm{NaNO}_{3}$ particles in the $\mathrm{SV}$ than with $\mathrm{NH}_{4} \mathrm{NO}_{3}$ par- 


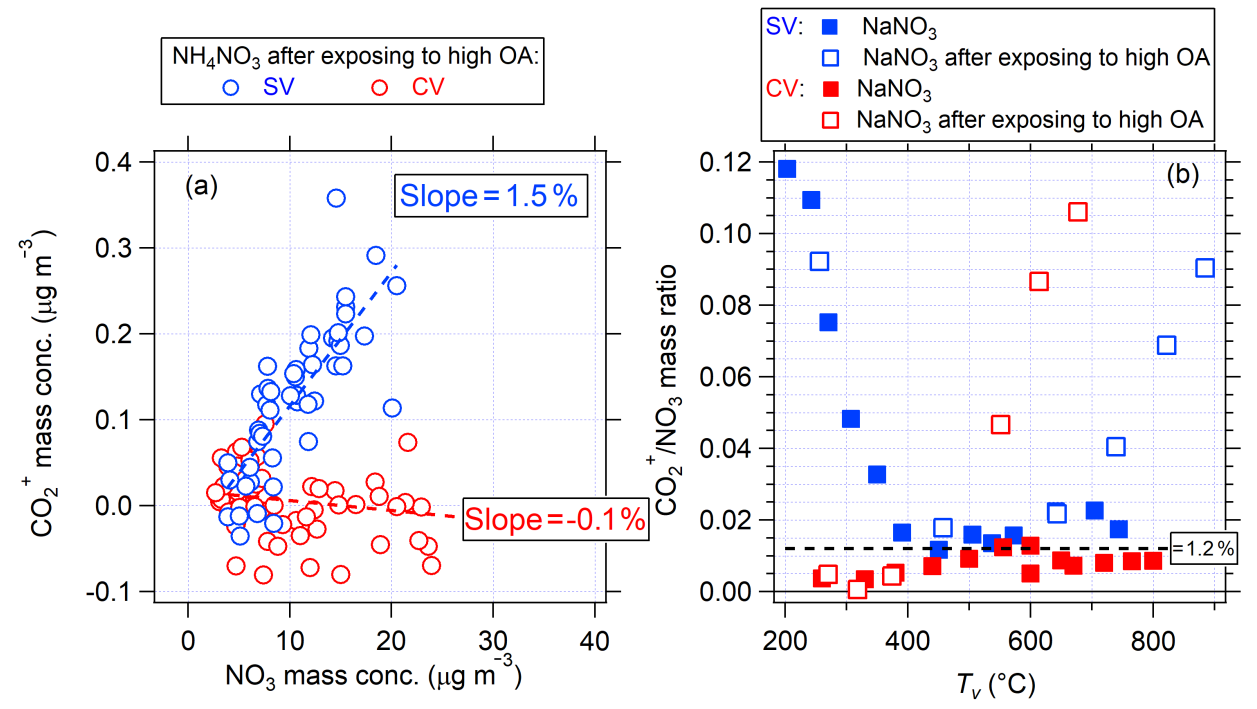

Figure 8. (a) Scatter plots of $\mathrm{CO}_{2}^{+}$and particulate nitrate signals when pure $\mathrm{NH}_{4} \mathrm{NO}_{3}$ particles were sampled into two AMSs with a SV and $\mathrm{CV}$ respectively. These data were collected after 4 days of exposing both AMS to a wide range of SOA mass concentrations (10$1000 \mu \mathrm{g} \mathrm{m}^{-3}$ ) from chamber studies. (b) Ratios of $\mathrm{CO}_{2}^{+}$to particulate nitrate vs. $T_{\mathrm{v}}$. All data are in nitrate-equivalent units. The data for $\mathrm{NaNO}_{3}$ after being exposed to OA were collected during a period similar to those shown in Fig. $4 \mathrm{a}$, while the other $\mathrm{NaNO}_{3}$ data were collected in a different period.

ticles have also been observed in this (Fig. 8b) and previous studies (Pieber et al., 2016).

\subsection{CE of standard inorganic species}

The $\mathrm{CE}$ of laboratory aerosol containing four inorganic species $\left(\mathrm{NH}_{4} \mathrm{NO}_{3},\left(\mathrm{NH}_{4}\right)_{2} \mathrm{SO}_{4}, \mathrm{NaNO}_{3}\right.$ and $\left.\mathrm{NH}_{4} \mathrm{Cl}\right)$ in the $\mathrm{CV}$ is investigated here. The ratio of the mass concentrations of monodisperse particles as calculated for the AMS (using $\mathrm{CE}=1$ ) and CPC-derived concentrations (hereafter referred to as "AMS / CPC mass ratio") are shown in Fig. 9 as a function of $T_{\mathrm{v}}$. To our knowledge, this is the first time that AMS CE has been reported as a function of $T_{\mathrm{V}}$ for SV. All the AMS / CPC mass ratios (interpreted as CE) were calculated based on the IE and RIE obtained at $550-600^{\circ} \mathrm{C}$. Field results suggest that RIE is not a strong function of temperature in the $350-600^{\circ} \mathrm{C}$ range (Jimenez et al., 2016). Particle sizes of $250-300 \mathrm{~nm}$ were used to avoid particle losses by any other mechanism than bounce at the vapourizer (Huffman et al., 2005; Liu et al., 2007; Bahreini et al., 2008). However, $d_{\mathrm{m}}=300 \mathrm{~nm}$ (mobility diameter) of $\mathrm{NaNO}_{3}$ corresponds to $d_{\mathrm{va}} \sim 680 \mathrm{~nm}\left(=d_{\mathrm{m}} \times\right.$ material density), which inadvertently exceeds the size range of $100 \%$ lens transmission $\left(d_{\mathrm{va}} \sim 550 \mathrm{~nm}\right.$ for a well-functioning standard lens, e.g. Knote et al., 2011). Thus a correction factor is required for correction of the $\mathrm{NaNO}_{3}$ data for lens transmission losses, so that the corrected ratio can be interpreted as $\mathrm{CE}$ due to vapourizer bounce only. Based on the measured lens transmission curves for the instruments used in this study (Fig. S2), lens transmission fractions $E_{\mathrm{L}}=0.6$ and 0.8 were applied to the AMS / CPC mass ratio of $300 \mathrm{~nm}$
$\mathrm{NaNO}_{3}$ in the $\mathrm{SV}$ and $\mathrm{CV}$ respectively. No lens transmission corrections are needed for the other species.

\subsection{1 $\mathrm{NH}_{4} \mathrm{NO}_{3}$}

The AMS / CPC nitrate mass ratio vs. $T_{\mathrm{v}}$ is shown in Fig. 9a1. An average ratio of $1.03 \pm 0.07$ (avg. \pm stdv; range: $0.89-1.12$ ) for $T_{\mathrm{v}}=200-750^{\circ} \mathrm{C}$ was observed for the SV. The variation of AMS / CPC mass ratios at other $T_{\mathrm{v}}$ compared to $600^{\circ} \mathrm{C}(<12 \%)$ was consistent with the reported $10 \%$ variation in the AMS response to ambient particles as $T_{\mathrm{V}}$ was rapidly varied (Docherty et al., 2015). The ratio of background signal (closed particle beam) to aerosol input (CPC mass) was small, and exhibited a continuous decrease (0.12 to 0.04 ) with $T_{\mathrm{v}}$, presumably due to somewhat slower vapourization at lower $T_{\mathrm{v}}$.

In the $\mathrm{CV}$, the AMS / CPC mass ratio of $\mathrm{NH}_{4} \mathrm{NO}_{3}$ was approximately 1 between 300 and $700^{\circ} \mathrm{C}$, with lower ratios $(\sim 0.6-0.8)$ at extreme $T_{\mathrm{v}}\left(T_{\mathrm{v}}<300^{\circ} \mathrm{C}\right.$ or $\left.T_{\mathrm{v}}>700^{\circ} \mathrm{C}\right)$. The decreased AMS / CPC mass ratio at low $T_{\mathrm{V}}$ may be ascribed to slower vapourization. Similarly to the SV, this was supported by a larger closed signal at lower $T_{\mathrm{v}}$, e.g. $\sim 0.12$ at $200{ }^{\circ} \mathrm{C}$ vs. $\sim 0.005$ at $500^{\circ} \mathrm{C}$. Possible reasons for the decrease at the highest $T_{\mathrm{v}}\left(>700^{\circ} \mathrm{C}\right)$ are stronger interactions of the analytes with the hot vapourizer surfaces, which is supported by a slightly higher nitrate closed signal observed at high $T_{\mathrm{v}}$, and/or a faster molecular speed reducing the effective ionization efficiency. To further examine this question, we study the aerosol signal decay and rise upon blocking and unblocking the particle beam (Fig. 10). 

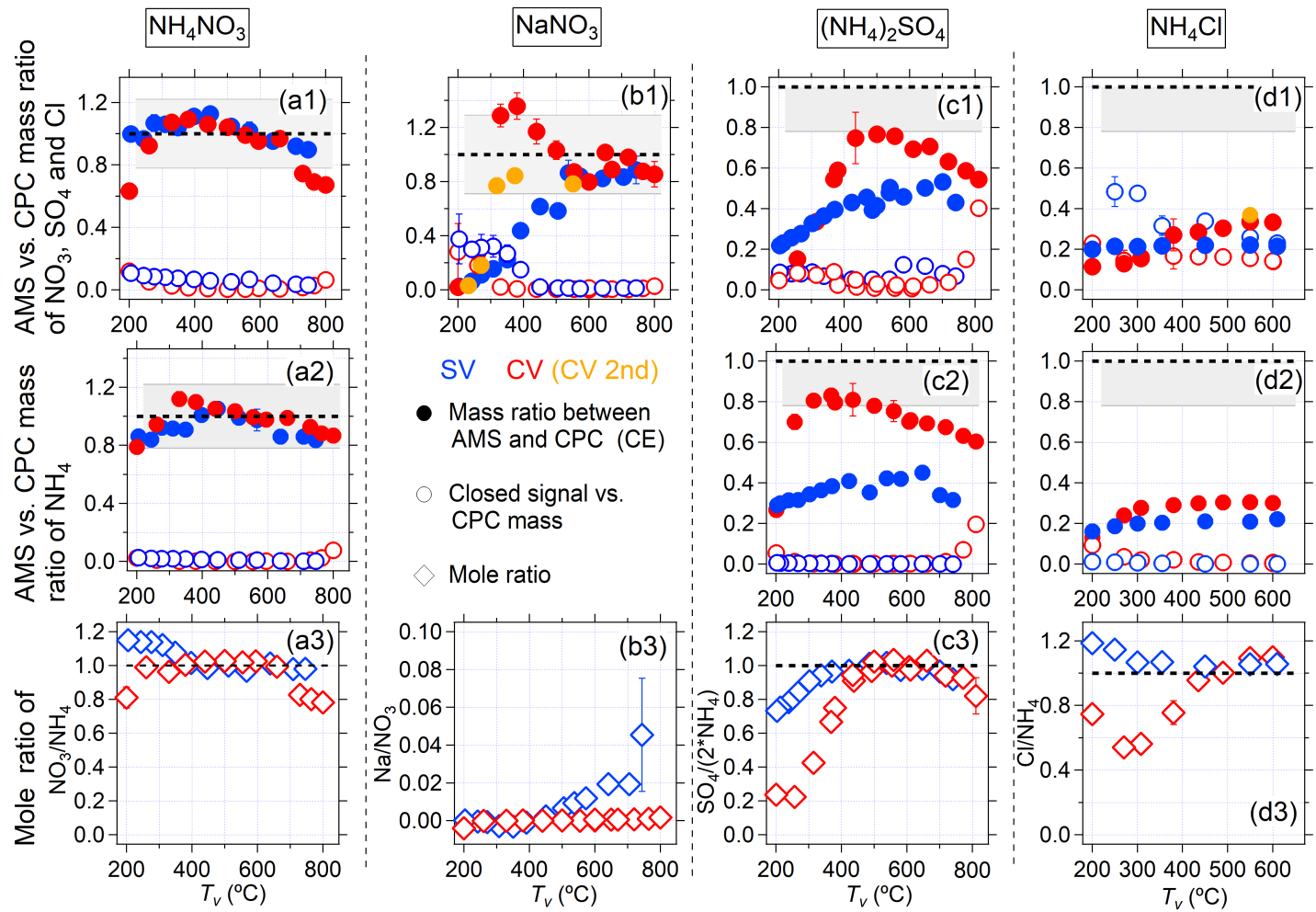

- Mass ratio between AMS and CPC (CE)

Closed signal vs. CPC mass Mole ratio
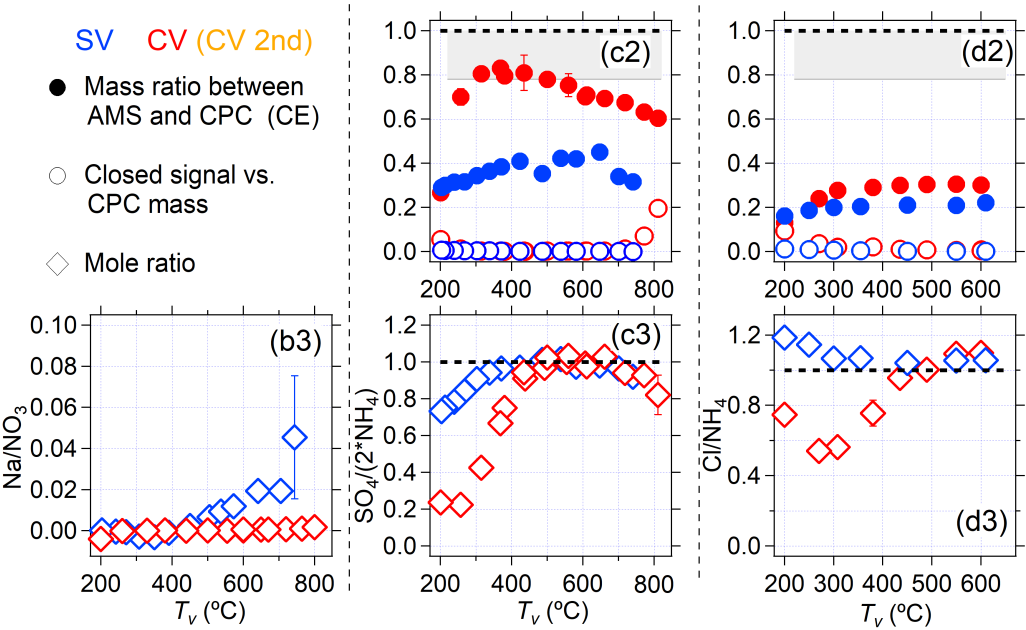

Figure 9. Ratio of mass concentration between AMS and CPC measurements (CE) from four inorganic species (dried monodisperse particles) of (a) $300 \mathrm{~nm} \mathrm{NH}_{4} \mathrm{NO}_{3}$, (b) $250 \mathrm{~nm}\left(\mathrm{NH}_{4}\right)_{2} \mathrm{SO}_{4}$, (c) $300 \mathrm{~nm} \mathrm{NaNO} 3$, (d) $300 \mathrm{~nm} \mathrm{NH} 4 \mathrm{Cl}$, as a function of $T_{\mathrm{V}}$ in the SV and CV. Apparent mole ratios between the anion and cation (a3, c3 and d3) and cation and anion (b3) are also shown (bottom row). The $\mathrm{NaNO}_{3} \mathrm{AMS} / \mathrm{CPC}$ mass ratios were corrected based on the measured lens transmission curve in Fig. S2 (see text) to account for the lens transmission loss. The orange traces in (c1) and (d1) are results from repeat $\mathrm{CV}$ experiments. The mole ratio of $\left(\mathrm{NH}_{4}\right)_{2} \mathrm{SO}_{4}$ is $\mathrm{SO}_{4}$ vs. $2 \mathrm{NH}_{4}$. $\mathrm{RIE}$ of sodium was assumed to be 1 here since no explicit RIE of $\mathrm{Na}$ has been reported to our knowledge, and since this species is both slow to vapourize and prone to surface ionization in the AMS. The grey area is the Monte Carlo propagated error for measured AMS / CPC mass ratios, assuming $10 \%$ error for CPC counting, $15 \%$ error for DMA size-selection, $5 \%$ for shape factor, $10 \%$ for RIE, and $15 \%$ error for lens transmission. Lens transmission error is only applied in the error calculation of $\mathrm{NaNO}_{3}$ calculation. Finally, a total uncertainty of $29 \%$ is estimated for $\mathrm{NaNO}_{3}$ and $22 \%$ for the others

During typical MS mode operation, the beam-open and beam-blocked (closed) positions are alternated every several seconds (usually $\sim 5 \mathrm{~s}$ ). During the particle beam modulation experiments, these intervals were extended to much larger values, typically $5-10 \mathrm{~min}$, to allow for studying the signal response at much longer times, similarly to the study performed by Drewnick et al. (2015). The time resolution used was $1-3 \mathrm{~s}$. Three $T_{\mathrm{v}}$ spanning the usable range (200, 600 and $850^{\circ} \mathrm{C}$ ) were selected to perform the experiments in both vapourizers, as shown in Fig. 10. For the medium $T_{\mathrm{v}}=600^{\circ} \mathrm{C}$, a rapid increase and decrease in the nitrate signal ( $\tau<1 \mathrm{~s}$ ) was observed in both vapourizers. $\tau$ is defined here as the lifetime of signal decay when closing the particle beam after a long period ( $>$ several minutes in this study) of exposure to incoming particles. It was estimated through an exponential fit to the relevant part of the signal time series. $\tau$ for the signal rise after a long period without particles impacting the vapourizer is not shown, since it varies in the same way. Note that the $\tau$ might change over time for sticky or semi-refractory species (e.g. $\mathrm{NaCl}$ or $\mathrm{FeCl}_{3}$ ) (Drewnick et al., 2015).

After blocking the particle beam, the nitrate signal decreased to $8 \%$ of the beam-open signal after $3 \mathrm{~s}$ in the SV and to $1 \%$ after $1 \mathrm{~s}$ in the CV. Thus faster nitrate decay in the CV than the SV has been observed. We speculate that the scattered particles onto a nearby surface of the ionization chamber could result in a slower decay due to the colder chamber surfaces. As the CV inhibits particle bouncing/scattering, this results a faster decay. This clearer separation of processes is one of the advantages of the $\mathrm{CV}$ over SV. At lower $T_{\mathrm{v}}=200^{\circ} \mathrm{C}$, the nitrate signal decays to $16 \%$ of the open signal in the SV after $3 \mathrm{~s}$ and to $24 \%$ in the CV after $2 \mathrm{~s}$ respectively, showing a slower decay of nitrate signal at lower temperatures. A slower rise of the nitrate signal at $T_{\mathrm{v}}=200^{\circ} \mathrm{C}$ was also observed in the $\mathrm{CV}$ upon unblocking the particle beam, which resulted in a lower open signal detection in the conventional MS mode (where the beam would be blocked again after a few seconds). Thus this experiment 

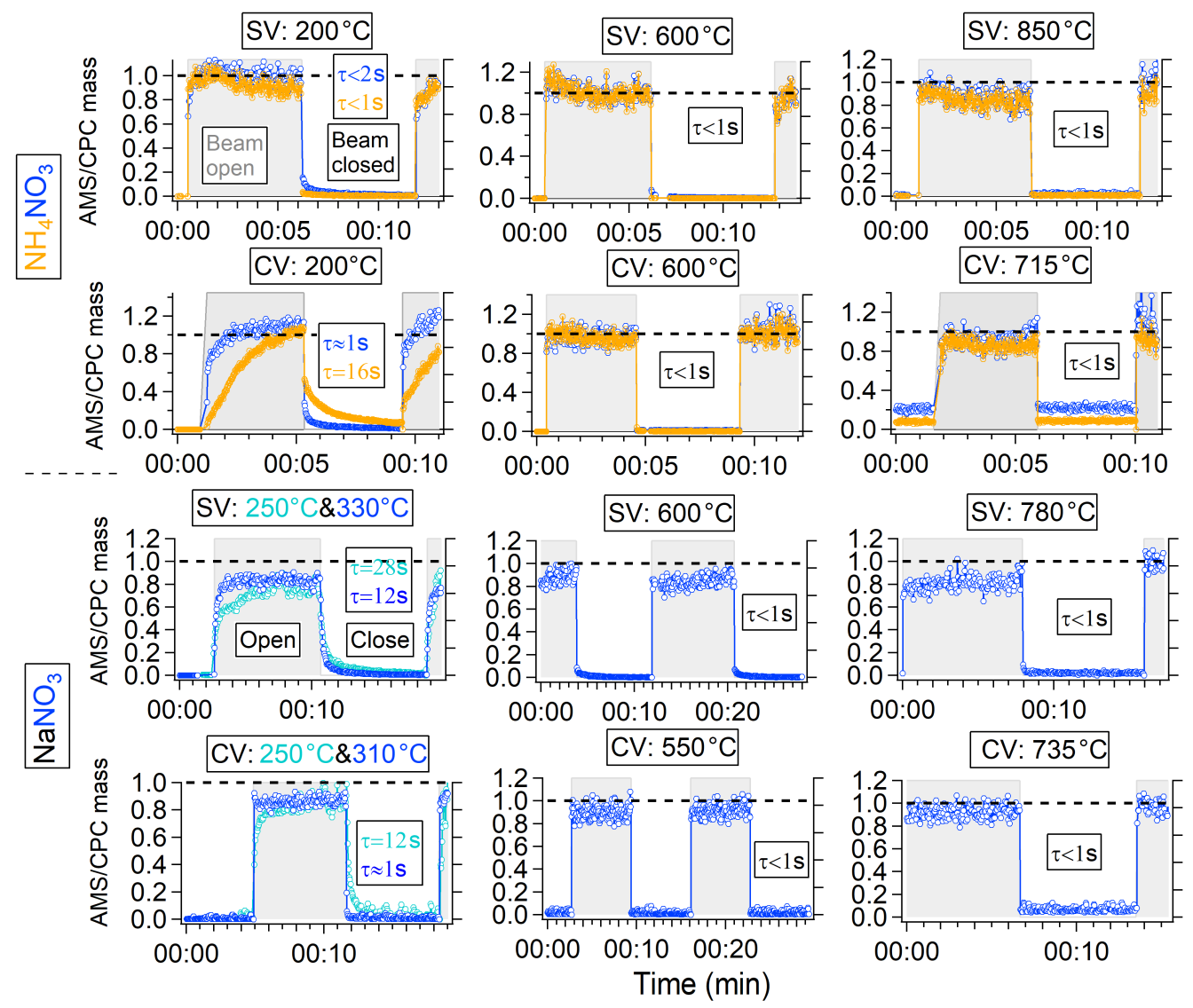

00:00

$00: 10$

Figure 10. Results of an experiment slowly alternating beam-open and beam-closed positions while sampling $\mathrm{NH}_{4} \mathrm{NO}_{3}$ and $\mathrm{NaNO}_{3}$ in the SV and CV. Note that the total signal (and not just the difference signal) is shown in all panels. The results from three/four different vapourizer temperatures (low, medium and high within the usable range) for each species are shown. $\tau$ is the lifetime of signal decay and was estimated through an exponential fit to the relevant part of the time series. $\tau$ for the rising signal is not shown, since it always varies in the same way.

indicates that the longer time for the vapours produced from nitrate to escape the $\mathrm{CV}$ (and possibly for vapourization) at lower $T_{\mathrm{V}}$ was the reason for the lower nitrate signal detected in this case. At the higher $T_{\mathrm{v}}$ of $850^{\circ} \mathrm{C}$, a faster decay of the nitrate signal $(3 \%$ of open signal in $3 \mathrm{~s})$ than at $600^{\circ} \mathrm{C}(8 \%)$ was observed in the SV. In the CV, the beam-blocked signal remained elevated $(\sim 20 \%$ of open signal) and constant for the rest of beam-blocked time $(\sim 5 \mathrm{~min})$. This elevated background signal at higher $T_{\mathrm{v}}\left(>700^{\circ} \mathrm{C}\right)$ may be due to either (1) the hotter surroundings of the ionizer cage containing deposited nitrate resulting in more desorption of nitrated vapours; and/or (2) stronger interactions between the species decomposing from nitrate and the hot vapourizer surfaces.

\subsection{2 $\mathrm{NaNO}_{3}$}

AMS / CPC mass ratios for $\mathrm{NaNO}_{3}$ are shown in Fig. 9b. As $T_{\mathrm{v}}$ increases from 200 to $700^{\circ} \mathrm{C}$, AMS / CPC mass ratios of $\mathrm{NaNO}_{3}$ in $\mathrm{SV}$ increased dramatically (from 0.02 to $\sim 0.85$ ), indicating a greatly improved detection of $\mathrm{NaNO}_{3}$ at higher
$T_{\mathrm{v}}\left(>500^{\circ} \mathrm{C}\right.$ ). When $T_{\mathrm{v}}$ was above $550^{\circ} \mathrm{C}$, the nitrate $\tau$ was less than $2 \mathrm{~s}$ (beam blocked $=7 \%$ of beam open at $T_{\mathrm{v}}=$ $600^{\circ} \mathrm{C}$ ), indicating that vapourization was fast enough for nitrate detection from $\mathrm{NaNO}_{3}$ in $\mathrm{MS}$ mode. The ratio of $\sim 0.85$ is indicative of a minor or particle bounce for $\mathrm{NaNO}_{3}$

In the CV, AMS / CPC mass ratios of $\mathrm{NaNO}_{3}$ showed a qualitatively similar positive trend with $T_{\mathrm{v}}$. However, the ratio in the $\mathrm{CV}$ peaked at a much lower $T_{\mathrm{V}}\left(300^{\circ} \mathrm{C}\right)$ than for $\mathrm{SV}$ $\left(500^{\circ} \mathrm{C}\right)$, indicating better detection of less-volatile species in the $\mathrm{CV}$, presumably due to the increased residence time and reduced bounce (or higher probability of finally vapourizing after multiple collisions inside the CV). For the beamopen and beam-blocked experiment (Fig. 10), much faster particle decay was observed in the $\mathrm{CV}\left(\tau \sim 1 \mathrm{~s}\right.$ at $\left.310^{\circ} \mathrm{C}\right)$ than in the $\mathrm{SV}\left(\tau \sim 12 \mathrm{~s}\right.$ at $\left.330^{\circ} \mathrm{C}\right)$ at these temperatures. This difference may be due to the geometry of the CV, which inhibits the particle bounce from the vapourizer to the surrounding colder ionizer surfaces, and this effect can lead to a slowly evolving signal in the SV. Above $550{ }^{\circ} \mathrm{C}$, the ratio in both vapourizers levelled off at $0.8-0.95$. The partial cause of 
the plateau of the AMS / CPC mass ratio for $\mathrm{NaNO}_{3}$ at less than 1 in the $\mathrm{CV}$ is probably due to the uncertainty of particle lens transmission loss correction. A full capture of $\mathrm{NaNO}_{3}$ $\left(E_{\mathrm{b}}=1\right)$ in the capture vapourizer was reported based on the AMS internal light scattering data (counting individual particles) (Xu et al., 2017). Another possible reason for lower $\mathrm{NO}_{3}$ detection efficiency is that a Jayne shape factor (similar to $\mathrm{NH}_{4} \mathrm{NO}_{3}$ ) might be needed to correct the $\mathrm{NaNO}_{3}$ density $\left(2.26 \mathrm{~g} \mathrm{~cm}^{-3}\right)$. The RIE of nitrate from $\mathrm{NaNO}_{3}$ might also be slightly lower than from $\mathrm{NH}_{4} \mathrm{NO}_{3}$ due to their different vapour precursors. Compared to the theoretical ion balance $($ mole ratio $=1)$, mole ratios between detected $\mathrm{Na}$ and $\mathrm{NO}_{3}$ in both vapourizers were very low $(<0.04)$ based on an assumed RIE of $\mathrm{Na}$ of 1 . Na is a semi-refractory species (probably exists as $\mathrm{Na}_{2} \mathrm{O}$ after thermal decomposition) that cannot be fully vapourized on the vapourizer, and it might retain some of the nitrate in the vapourizer for a longer period.

\subsection{3 $\left(\mathrm{NH}_{4}\right)_{2} \mathrm{SO}_{4}$}

Pure $\left(\mathrm{NH}_{4}\right)_{2} \mathrm{SO}_{4}$ is a less-volatile species and has been reported to have an $E_{\mathrm{b}}$ of $0.2-0.4(200 \mathrm{~nm})$ in the SV at $T_{\mathrm{v}}=600^{\circ} \mathrm{C}$ when sampling at ambient RH below its deliquescence point (Allan et al., 2004a; Matthew et al., 2008), while dry mixed ammonium sulfate-organic ambient particles typically have $E_{\mathrm{b}} \sim 0.5$ (Middlebrook et al., 2012). In this study, a positive dependence of the AMS / CPC $\mathrm{SO}_{4}$ mass ratio vs. $T_{\mathrm{v}}$ was observed for the $\mathrm{SV}$, increasing from 0.2 at $T_{\mathrm{v}}=200^{\circ} \mathrm{C}$ to 0.55 at $T_{\mathrm{v}}>500^{\circ} \mathrm{C}$ (Fig. 9c1). This increase is likely due to both a lower particle bounce fraction and also faster vapourization. The $\tau$ of $\mathrm{SO}_{4}$ after blocking the particle beam was $26 \mathrm{~s}$ at $T_{\mathrm{v}}=310^{\circ} \mathrm{C}$ and $<2.5 \mathrm{~s}$ at $T_{\mathrm{v}}=850^{\circ} \mathrm{C}$ (Fig. 11).

In the $\mathrm{CV}$, AMS / CPC mass ratios of $\mathrm{SO}_{4}$ were reproducibly $0.7-0.8$ at $T_{\mathrm{v}}=400-700^{\circ} \mathrm{C}$ based on multiple experiments (Fig. 11). The AMS / CPC mass ratios of dry $\left(\mathrm{NH}_{4}\right)_{2} \mathrm{SO}_{4}$ in the $\mathrm{CV}$ that are less than 1 are consistent with the results of $\mathrm{Xu}$ et al. (2017). The $\sim 25 \%$ missing signal suggests that a small fraction of pure $\left(\mathrm{NH}_{4}\right)_{2} \mathrm{SO}_{4}$ particles might still bounce on the edge of the $\mathrm{CV}$ (interpreted as $E_{\mathrm{s}}$ ) or that they may still bounce out of the CV without vapourizing inside the $\mathrm{CV}$ cavity. $E_{\mathrm{s}}$ probably contribute at least a few percent to $\left(\mathrm{NH}_{4}\right)_{2} \mathrm{SO}_{4}$ mass loss in the $\mathrm{CV}$ based on beam-width probe experiment results reported by Huffman et al. (2005) compared with the CV inlet width $(2.54 \mathrm{~mm}$, as labelled in Fig. 1). However, compared to the ratios of $\sim 0.45-$ 0.55 in $\mathrm{SV}$, pure $\left(\mathrm{NH}_{4}\right)_{2} \mathrm{SO}_{4}$ is more efficiently detected in the CV. The beam-open and beam-blocked comparison also showed a much faster decay of $\mathrm{SO}_{4}$ in the $\mathrm{CV}$ than in the $\mathrm{SV}$ for similar $T_{\mathrm{V}}$, e.g. $\tau<2 \mathrm{~s}$ in the $\mathrm{CV}$ vs. $\tau=13 \mathrm{~s}$ in the $\mathrm{SV}$ at $T_{\mathrm{v}}=550-610^{\circ} \mathrm{C}$. As discussed above, the faster decay of signals in the $\mathrm{CV}$ is likely due to the lower fraction of particle bouncing to the surrounding ionizer cage than with the SV. The reduced AMS / CPC mass ratios at lower $T_{\mathrm{V}}$ in both vapourizers were probably caused by slower vapouriza- tion of sulfate (slow rise and decay signal in Fig. 11) and/or enhanced particle bounce at low $T_{\mathrm{v}}$. The reason for the lower AMS / CPC mass ratio at higher $T_{\mathrm{v}}\left(>700^{\circ} \mathrm{C}\right)$ in the $\mathrm{CV}$ may be due to enhanced interactions with the hot vapourizer surfaces, as hypothesized above for nitrate. Enhanced beam-blocked signal was observed at high $T_{\mathrm{v}}$ (Fig. 9c2), as observed for $\mathrm{NH}_{4} \mathrm{NO}_{3}$ and $\mathrm{NaNO}_{3}$.

\subsection{4 $\mathrm{NH}_{4} \mathrm{Cl}$}

As discussed above, chloride appears to be very sticky on the vapourizer/ionizer surface, and is only slowly removed from the AMS background (Drewnick et al., 2015). Thus, the instrument history (e.g. chloride sampled and/or recent $T_{\mathrm{v}}$ history) or set up (e.g. different duty cycles) may influence $\mathrm{NH}_{4} \mathrm{Cl}$ detection.

Huffman et al. (2009b) reported that $\mathrm{NH}_{4} \mathrm{Cl}$ particles were vapourized in a thermodenuder at a higher temperature than $\mathrm{NH}_{4} \mathrm{NO}_{3}$ but a lower temperature than $\left(\mathrm{NH}_{4}\right)_{2} \mathrm{SO}_{4}$. However, the melting point/decomposition point of pure $\mathrm{NH}_{4} \mathrm{Cl}$ is $\sim 330^{\circ} \mathrm{C}$ (Zhu et al., 2007), which is higher than those of $\left(\mathrm{NH}_{4}\right)_{2} \mathrm{SO}_{4}\left(235-280^{\circ} \mathrm{C}\right)$ (Haynes, 2015). AMS / CPC mass ratios of $\mathrm{Cl}$ from $\mathrm{NH}_{4} \mathrm{Cl}(300 \mathrm{~nm})$ in the $\mathrm{SV}$ were reproducibly $0.2-0.25$, possibly due to particle bounce and slow vapourization of bounced particle from the ionizer cage surfaces. High background signals and a slow timescale of change were observed at all $T_{\mathrm{V}}$ for the SV (Figs. 9 and 11), consistent with the importance of the second hypothesis.

Slightly larger AMS / CPC mass ratios (0.27-0.35) were observed for the CV at $T_{\mathrm{v}}>400^{\circ} \mathrm{C}$. Two separate AMSs showed similar $\mathrm{AMC} / \mathrm{CPC}$ ratios $(0.33-0.37)$ at $T_{\mathrm{v}}=$ $550-600{ }^{\circ} \mathrm{C}$. The beam-open and beam-blocked experiment showed a faster chloride decay in the $\mathrm{CV}(\tau=5.2 \mathrm{~s})$ than the SV $(\tau=104 \mathrm{~s})$ at $550-600^{\circ} \mathrm{C}$, mainly determined by the slower decaying $\mathrm{Cl}^{+}$ion (while the $\mathrm{HCl}^{+}$ion response was faster).

\subsection{5 $\mathrm{NH}_{4}$ from $\mathrm{NH}_{4} \mathrm{NO}_{3},\left(\mathrm{NH}_{4}\right)_{2} \mathrm{SO}_{4}$ and $\mathrm{NH}_{4} \mathrm{Cl}$}

For both the $\mathrm{SV}$ and $\mathrm{CV}$, the AMS / CPC mass ratios of $\mathrm{NH}_{4}$ showed similar values and $T_{\mathrm{v}}$ dependences to their anions (Fig. 9). This is an indication that particle bounce played an important role for AMS / CPC mass ratios less than 1.

At medium $T_{\mathrm{v}}\left(500-650^{\circ} \mathrm{C}\right), \mathrm{NH}_{4}$ from the three species in both vapourizers all showed very low background signals $(<0.5 \%)$. In the beam-open and beam-blocked experiment, the decay lifetime of $\mathrm{NH}_{4}$ was below 1-2 s, which was similar to or faster than the anion decays. The faster vapourization of $\mathrm{NH}_{4}$ than for the anion has also been reported before for vapourization of ambient aerosols in a thermodenuder, where aerosols became more acidic when being heated (Huffman et al., 2009a). Despite the lower background signals of $\mathrm{NH}_{4}$, low AMS / CPC mass ratios of $\mathrm{NH}_{4}$ from $\left(\mathrm{NH}_{4}\right)_{2} \mathrm{SO}_{4}$ and $\mathrm{NH}_{4} \mathrm{Cl}$ in both vapourizers was observed, strongly suggesting particle bouncing as the most likely explanation for the 

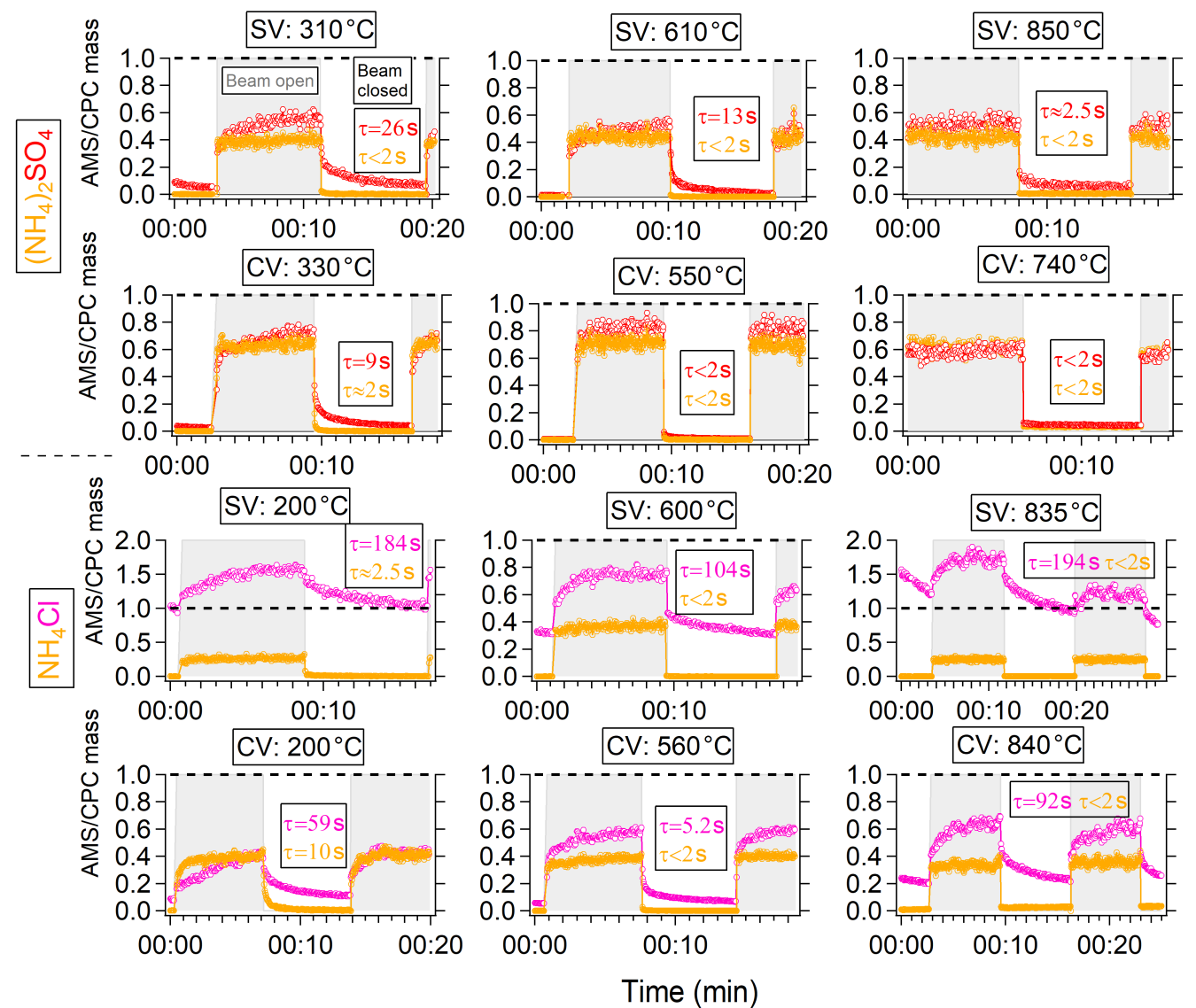

Time (min)

Figure 11. Results of an experiment with slowly alternating beam-open and beam-closed positions while sampling $\mathrm{NaNO}_{3}$ and $\mathrm{NH}_{4} \mathrm{Cl}$ in the SV and CV. Note that the total signal (and not just the difference signal) is shown in all panels. The results from three or four different vapourizer temperatures (low, medium and high within the usable range) for each species are shown. $\tau$ is the lifetime of signal decay and was estimated through an exponential fit to the relevant part of the time series. $\tau$ for the rising signal is not shown, since it varies in the same way.

lower ratios of $\left(\mathrm{NH}_{4}\right)_{2} \mathrm{SO}_{4}$ and $\mathrm{NH}_{4} \mathrm{Cl}$ observed in the $\mathrm{CV}$ as well.

At lower $T_{\mathrm{v}}\left(<350^{\circ} \mathrm{C}\right), \mathrm{NH}_{4}$ from the three inorganic species in the SV showed similar decay lifetimes $(<2 \mathrm{~s})$ to the one at medium $T_{\mathrm{v}}\left(500-650^{\circ} \mathrm{C}\right)$ and was much faster than their anion decays (2-184 s). $\mathrm{NH}_{4}$ decay in the $\mathrm{CV}$ at low $T_{\mathrm{V}}$ $\left(\sim 200-330^{\circ} \mathrm{C}\right.$ ) exhibited a $\tau \sim 16 \mathrm{~s}$ for $\mathrm{NH}_{4} \mathrm{NO}_{3}, \sim 2 \mathrm{~s}$ for $\left(\mathrm{NH}_{4}\right)_{2} \mathrm{SO}_{4}$ and $10 \mathrm{~s}$ for $\mathrm{NH}_{4} \mathrm{Cl}$, which was longer than $\mathrm{NH}_{4}$ in the $\mathrm{SV}$ at a similarly low $T_{\mathrm{v}}$ range. The longer $\mathrm{NH}_{4}$ decay suggested a slower release of $\mathrm{NH}_{3}(\mathrm{~g})$ for the $\mathrm{CV}$ than the $\mathrm{SV}$ at this low $T_{\mathrm{v}}$ range $\left(<350{ }^{\circ} \mathrm{C}\right)$, the reasons for which are unclear. The $\mathrm{NH}_{4}$ decay in the $\mathrm{CV}$ was still faster than their anions of $\mathrm{SO}_{4}$ and $\mathrm{Cl}$, which may explain why AMS / CPC mass ratios of $\mathrm{NH}_{4}$ were higher than $\mathrm{SO}_{4}$, and $\mathrm{Cl}$ and anion/cation ratios $(0.2$ to 1$)$ decreased at lower $T_{\mathrm{v}}\left(400^{\circ} \mathrm{C}\right.$; Fig. 9b2-3 and d2-3). At higher $T_{\mathrm{v}}$, AMS / CPC mass ratios of $\mathrm{NH}_{4}$ exhibited similar ratios to their anions. A small background enhancement at higher $T_{\mathrm{v}}$ in the $\mathrm{CV}$ was also observed.

\subsubsection{Implications for vapourization mechanisms in the AMS}

It has recently been suggested that a major fraction of $\mathrm{NH}_{4} \mathrm{NO}_{3}$ and $\left(\mathrm{NH}_{4}\right)_{2} \mathrm{SO}_{4}$ vapourize as intact salts in the AMS (Murphy, 2016, 2017). Separate vapourization to $\mathrm{NH}_{3}(\mathrm{~g})$ and $\mathrm{H}_{x} \mathrm{NO}_{y}(\mathrm{~g})$ followed by their separate ionization can explain the high similarity of the ammonium fragmentation pattern to that of $\mathrm{NH}_{3}(\mathrm{~g})$ in the NIST EI database (Linstrom and Mallard, 2016) (Fig. 4). It can also explain constancy in the fragmentation pattern of ammonium across vapourizers and $T_{\mathrm{v}}$ (Fig. 4), despite major simultaneous changes on the observed fragmentation patterns of sulfate and nitrate. These very different fragmentation behaviours and trends between the cation and anion would be unexpected if inorganic species vapourized as intact salts. If molecular salts were vapourized, species such as $\mathrm{NH}_{4} \mathrm{NO}_{3}^{+}$, $\left(\mathrm{NH}_{4}\right)_{2} \mathrm{SO}_{4}^{+}$, and $\mathrm{NH}_{4} \mathrm{Cl}^{+}$would form after ionization. Since the fragmentation chemistry of molecular cations is highly dependent on the species (e.g. McLafferty and Turecek, 
1993), each would fragment in characteristic ways, leading to consistent trends for the cation and anion and potentially to some differences in the product ions from ammonium. The different $\tau$ of $\mathrm{NH}_{4}$ and its associated anions after blocking the particle beam (Figs. 10-11) also suggest that thermal decomposition, followed by separate interactions with hot surfaces, is an important step in particle detection in the AMS. Section S1 in the Supplement further summarizes the evidence on this topic.

According to Eq. (2) in Murphy (2016), and in the absence of other effects, measured signal intensities and timescales should follow a $1 / \sqrt{T_{\mathrm{v}}}$ dependence as $T_{\mathrm{v}}$ is varied. Such a dependence is not observed in SV data, either for single particle timescales of pure species or for total signal from ambient particles, indicating the importance of other effects neglected in the Murphy model (Jimenez et al., 2016). This may be at least partly due to the fact that vapourization occurs at $T<T_{\mathrm{v}}$ due to evaporative cooling (Saleh et al., 2017). This point can now be evaluated for the CV using the AMS / CPC mass ratio data in Fig. 9 (replotted in Fig. S3), since the data are only calibrated with the RIEs determined at $\sim 600^{\circ} \mathrm{C}$. Such a dependence appears to be observed for three of the four species for part of the temperature profile. This suggests that the Murphy model may be a closer approximation of AMS detection when the CV is used, possibly because important SV processes such as particle bounce onto colder ionizer surfaces are suppressed with the CV. The different dependences observed for the SV in most cases highlight the substantial differences between the SV and CV in detection properties.

\subsection{Size distribution measurements}

\subsubsection{Size-resolved detection of ions at $T_{\mathrm{v}} \sim 500-650{ }^{\circ} \mathrm{C}$}

The determination of particle size distributions in the AMS is based on measuring size-dependent particle flight times or PToF, which are on the timescale of milliseconds. Prerequisites of precise size distribution determination are rapid particle vapourization and detection times, which need to be much faster than the millisecond PToF timescale, ideally $10 \mathrm{~s}$ of microseconds. When the rates of vapourization and/or decomposition are reduced, the resolution of the AMS sizing is also reduced. This is a more stringent requirement than quantifying the total mass concentrations in MS mode, which only require vapourization and detection to be on the order of $\sim 5 \mathrm{~s}$, where the particle beam is alternately blocked or sampled. In this section we evaluate the ability to measure size distributions with the $\mathrm{CV}$. Results from the inorganic species $250 \mathrm{~nm}\left(\mathrm{NH}_{4}\right)_{2} \mathrm{SO}_{4}, 300 \mathrm{~nm} \mathrm{NH} \mathrm{NO}_{3}, 300 \mathrm{~nm} \mathrm{NaNO}$, as well as polydispersed organic nitrates generated from $\mathrm{NO}_{3}$ radical + monoterpene chamber studies, are discussed below (Fig. 12).

Generally, ions from each species showed similar rise times in the SV $(\sim 100 \mu$ s, Fig. 12), indicating that aerosols were quickly vapourized and detected after impact on the open SV surface. The rise time is defined as the time interval from $10 \%$ of peak height to the peak. Compared to the SV, most PToF distributions in the CV exhibited a slower rise, and larger differences for different ions/species, consistent with results for $\mathrm{NH}_{4} \mathrm{NO}_{3}$ and $\left(\mathrm{NH}_{4}\right)_{2} \mathrm{SO}_{4}$ in the $\mathrm{CV}$ from $\mathrm{Xu}$ et al. (2017). Although it will lead to lower sizing resolution, it clearly shows that size distributions can still be measured with the CV. The lag of the particle detection times indicates that a CV-specific particle size calibration is needed, as substantial errors would arise if using a calibration curve from the SV. The lag times between the CV and SV are different for different species (e.g. $0.5 \mathrm{~ms}$ for $\mathrm{NO}_{3}$ and $1.3 \mathrm{~ms}$ for $\mathrm{SO}_{4}$ ), which suggests that the $\mathrm{CV}$ could benefit from different size calibration curves for externally mixed aerosols. The earlier rise of $\mathrm{NO}_{2}^{+}$than $\mathrm{NO}^{+}$in inorganic nitrates in the $\mathrm{CV}$ may be due to reduced surface interactions of $\mathrm{HNO}_{3}(\mathrm{~g})$ and $\mathrm{NO}_{2}(\mathrm{~g})$ (which can yield $\mathrm{NO}_{2}^{+}$ions) than for $\mathrm{NO}(\mathrm{g})$. In contrast to inorganic nitrates, $\mathrm{NO}_{2}^{+}$from organic nitrates showed a delayed tail vs. $\mathrm{NO}^{+}$. This tail has also been seen in the $\mathrm{CV}$ for other organic nitrates from $\mathrm{NO}_{3}$ radical + monoterpene chamber studies, and might be a useful approach to identify and quantify organic nitrates (e.g. Fry et al., 2013) when using the $\mathrm{CV}$.

$\mathrm{NH}_{4}$ from inorganic species in the CV showed a slightly earlier rise than $\mathrm{NO}^{+}$and $\mathrm{SO}_{2}^{+} / \mathrm{SO}^{+}$(Fig. 12e and g). This may be associated with faster vapourization of $\mathrm{NH}_{3}(\mathrm{~g})$ and faster effusion out of the $\mathrm{CV}$ due to its lower molecular weight and reduced surface interactions.

\subsubsection{Distribution as a function of temperature}

PToF distributions of monodisperse particles from three stan-

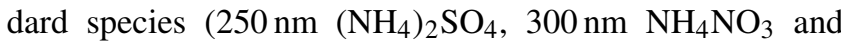
$300 \mathrm{~nm} \mathrm{NaNO} \mathrm{N}_{3}$ ) in both vapourizers as a function of $T_{\mathrm{v}}$ are shown in Fig. 13a1-c1 and a2-c2. Figure 13a-c3 is a summary of FWHM as a function of $T_{\mathrm{v}}$ based on Fig. 13a1$\mathrm{c} 1$ and a2-c2. In the following discussion, three different aspects including transition $T_{\mathrm{v}}$, peak broadening, and PToF vs. MS mode are discussed. The PToF distribution of each species reported is the sum for all its ions, and thus is a convolution of slightly different behaviours from each ion, as shown for example in Fig. 12.

\section{Transition $T_{\mathrm{v}}\left(T_{\mathrm{v}, \mathrm{t}}\right)$}

$T_{\mathrm{v}, \mathrm{t}}$ is defined as the $T_{\mathrm{v}}$ above which the measured particle distribution is no longer broadened by slow vapourization effects $(<1 \mathrm{~ms}$ for nitrate and sulfate in the SV, $2 \mathrm{~ms}$ for sulfate in the $\mathrm{CV}$ ). Above this $T_{\mathrm{v}}$, stable peak shapes and similar peak widths are typically observed (Fig. 13a3c3). $T_{\mathrm{v}, \mathrm{t}}$ appears to be mainly a function of species volatility with values for $\mathrm{NH}_{4} \mathrm{NO}_{3}\left(\sim 280^{\circ} \mathrm{C}\right)<\left(\mathrm{NH}_{4}\right)_{2} \mathrm{SO}_{4}$ $\left(380^{\circ} \mathrm{C}\right)<\mathrm{NaNO}_{3}\left(\sim 630^{\circ} \mathrm{C}\right)$ in the $\mathrm{SV}$. This sequence is similar to the order of reported melting point trends 


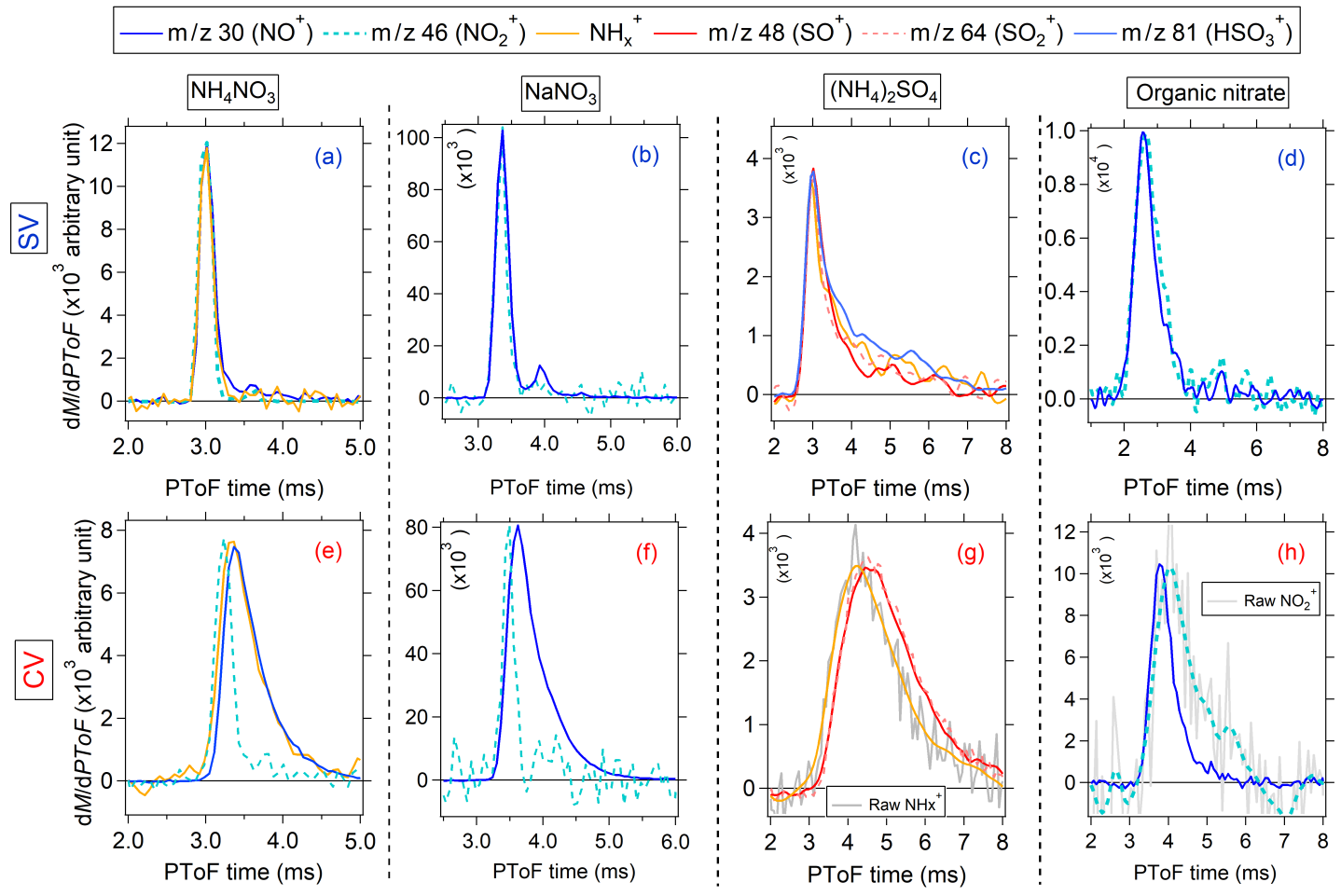

Figure 12. Size-resolved detection (using the PToF acquisition mode) for major ions from $300 \mathrm{~nm} \mathrm{NH}_{4} \mathrm{NO}_{3}, 300 \mathrm{~nm} \mathrm{NaNO}, 250 \mathrm{~nm}$ $\left(\mathrm{NH}_{4}\right)_{2} \mathrm{SO}_{4}$ and chamber-produced organic nitrate in the $\mathrm{SV}$ and $\mathrm{CV}$ at $T_{\mathrm{V}} \sim 500-650^{\circ} \mathrm{C}$. The PToF distributions of $\mathrm{NH}_{x}^{+}$in $(\mathrm{g})$ and of $\mathrm{NO}_{2}^{+}$in (h) were smoothed.

for those species: $\mathrm{NH}_{4} \mathrm{NO}_{3}: 169^{\circ} \mathrm{C}<\left(\mathrm{NH}_{4}\right)_{2} \mathrm{SO}_{4}$ : $235-$ $280^{\circ} \mathrm{C}<\mathrm{NaNO}_{3}: 306^{\circ} \mathrm{C}$ (Haynes, 2015), as well as their boiling points, as shown in Fig. 14. Similar positive trends were also observed in the $\mathrm{CV}$, where $T_{\mathrm{v}, \mathrm{t}}$ of $\mathrm{NH}_{4} \mathrm{NO}_{3}$ and $\left(\mathrm{NH}_{4}\right)_{2} \mathrm{SO}_{4}$ in the $\mathrm{CV}$ were similar for $\mathrm{NO}_{3}\left(\sim 200^{\circ} \mathrm{C}\right)$ and $\mathrm{SO}_{4}\left(370^{\circ} \mathrm{C}\right)$ with the $\mathrm{SV}$, and $T_{\mathrm{v}, \mathrm{t}}$ of $\mathrm{NaNO}_{3}$ is slightly lower than the $\mathrm{SV}\left(630^{\circ} \mathrm{C}\right)$. The lower $T_{\mathrm{v}, \mathrm{t}}$ of $\mathrm{NaNO}_{3}$ was probably due to less particle bounce and thus less delayed particle signals (Robinson et al., 2017) in the CV than SV. $\mathrm{NH}_{4}$ from $\mathrm{NH}_{4} \mathrm{NO}_{3}$ in the $\mathrm{CV}$ show a higher $T_{\mathrm{v}, \mathrm{t}}\left(380^{\circ} \mathrm{C}\right)$ than in the $\mathrm{SV}\left(280^{\circ} \mathrm{C}\right)$. A slower vapourization of $\mathrm{NH}_{4}$ than $\mathrm{NO}_{3}$ for the CV at low $T_{\mathrm{V}}$ was also observed in the beamopen and beam-blocked experiment (Fig. 10).

The relationship between $T_{\mathrm{v}, \mathrm{t}}$ and melting/boiling points could probably be used for estimating whether pure species are detected in AMS sizing mode. For example, the anion of $\mathrm{NaNO}_{3}$ or species with lower than or similar melting points to $\mathrm{NaNO}_{3}$, e.g. $\mathrm{MgNO}_{3}\left(129^{\circ} \mathrm{C}\right.$ or $\mathrm{KNO}_{3}\left(334^{\circ} \mathrm{C}\right)$, can likely be detected and quantified by the $\mathrm{CV}$ at $600^{\circ} \mathrm{C}$ in both MS and PToF modes. Further research on less-volatile species detection in the CV AMS, as well as the correlation of their fast detection $T_{\mathrm{v}}$ with melting and boiling points, is recommended.

The peak widths of $\mathrm{NH}_{4} \mathrm{NO}_{3}$ (both $\mathrm{NH}_{4}$ and $\mathrm{NO}_{3}$ ) at higher $T_{\mathrm{v}}\left(>700^{\circ} \mathrm{C}\right)$ start to broaden in the $\mathrm{CV}$. The explicit reason for this broadening is unknown.

\section{Peak broadening in CV}

For monodisperse particles, the peak width of the AMS PToF distribution is primarily governed by thermal vapourization and decomposition rates and rate of effusion of particle vapours to exit the CV (Drewnick et al., 2015). The latter mainly depends on $T_{\mathrm{v}}$, interaction between particle and vapourizer surface, vapourizer design and molecular speeds. In the $\mathrm{SV}$ for $T_{\mathrm{v}}>T_{\mathrm{v}, \mathrm{t}}$ (Fig. 13), the peak width of three species followed the order of $\mathrm{NH}_{4} \mathrm{NO}_{3}<\mathrm{NaNO}_{3}<\left(\mathrm{NH}_{4}\right)_{2} \mathrm{SO}_{4}$, all within $0.5 \mathrm{~ms}$.

Compared to the SV, PToF distributions in the $\mathrm{CV}$ showed broader peak widths, indicating longer vapour desorption/escape times. The peak width ratios between the CV and SV, defined as broadening ratios, vary widely between species: $\sim 5.5$ for $\left(\mathrm{NH}_{4}\right)_{2} \mathrm{SO}_{4}, 2$ for $\mathrm{NH}_{4} \mathrm{NO}_{3}$ and 1.8 for $\mathrm{NaNO}_{3}$. The broadened peaks in the $\mathrm{CV}$, leading to lower particle size resolution, degrade size distribution measurements in laboratory studies with monodisperse particles. For example, a small doubly charged peak of $\mathrm{NaNO}_{3}$, observed with the SV cannot be separated in the CV (Fig. 13b1-2). However, size distributions in ambient air tend to be broad, and when the size calibration curve of $\left(\mathrm{NH}_{4}\right)_{2} \mathrm{SO}_{4}$ is applied, a consistent size distribution measurement between the SV and $\mathrm{CV}$ is found, suggesting that the size distribution measurement in the CV is still useful (Hu et al., 2017). 

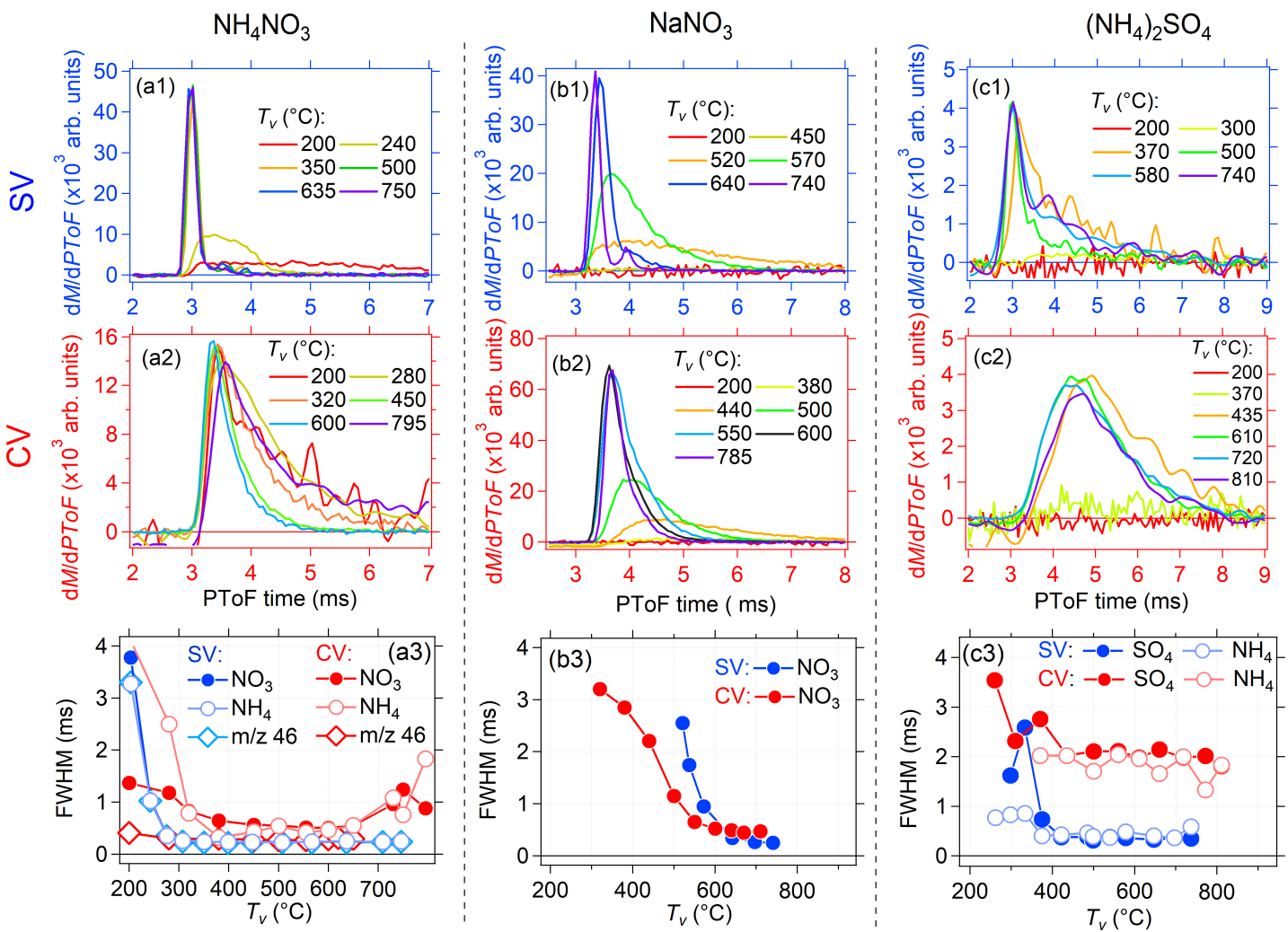

Figure 13. Size-resolved detection of (a) $250 \mathrm{~nm}\left(\mathrm{NH}_{4}\right)_{2} \mathrm{SO}_{4}$, (b) $300 \mathrm{~nm} \mathrm{NH} \mathrm{NO}_{3}$ and (c) $300 \mathrm{~nm} \mathrm{NaNO} 3$ using the PToF acquisition mode from the $\mathrm{SV}$ and $\mathrm{CV}$ as a function of $T_{\mathrm{V}}$. Particle peak widths of $(\mathbf{a} 3) \mathrm{NH}_{4} \mathrm{NO}_{3},(\mathbf{b 3}) \mathrm{NaNO}_{3}$ and $(\mathbf{c} 3)\left(\mathrm{NH}_{4}\right)_{2} \mathrm{SO}_{4}$ as a function of $T_{\mathrm{V}}$ are also shown.

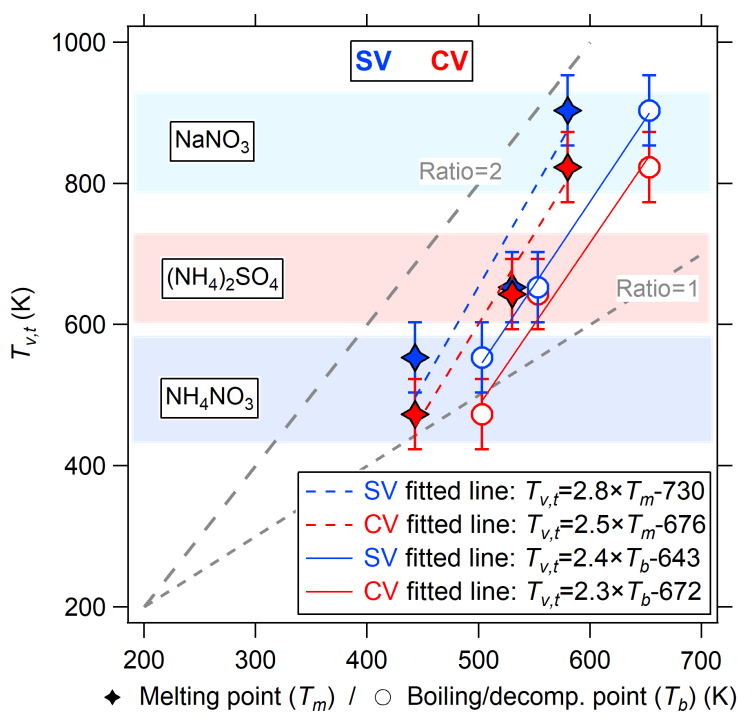

Figure 14. Scatter plot between transition $T_{\mathrm{V}}\left(T_{\mathrm{V}, \mathrm{t}}\right)$ and melting points $\left(T_{\mathrm{m}}\right)$ and boiling/decomposition points $\left(T_{\mathrm{b}}\right)$ of three standard species in both $\mathrm{SV}$ and $\mathrm{CV}$. The boiling point of $\left(\mathrm{NH}_{4}\right)_{2} \mathrm{SO}_{4}$ is its decomposition temperature (Haynes, 2015).

\section{Comparison of total detected signal in PToF vs. MS mode}

As discussed above, the MS and PToF modes integrate detection timescales of milliseconds and seconds respectively. Thus the total signal ratio between PToF and MS modes can be used as an alternative tool for studying the vapourization rates of different species, as shown in Fig. 14.

For $\mathrm{NH}_{4} \mathrm{NO}_{3}, \mathrm{PToF} / \mathrm{MS}$ of both vapourizers at low $T_{\mathrm{V}}\left(200-400^{\circ} \mathrm{C}\right)$ showed a continuously increasing trend, consistent with faster vapourization and decomposition/desorption as $T_{\mathrm{v}}$ increased (Fig. 15a). PToF/MS $\sim 1$ for $\mathrm{NO}^{+}$and $\mathrm{NO}_{2}^{+}$was observed in both vapourizers for $T_{\mathrm{v}}=450-700^{\circ} \mathrm{C}$. For $T_{\mathrm{v}}>650^{\circ} \mathrm{C}$, the PToF/MS of $\mathrm{NO}^{+}$ and $\mathrm{NO}_{2}^{+}$continuously decreased in the $\mathrm{CV}$, suggesting a less efficient quantification from PToF than MS mode, in agreement with the broadened PToF peaks (Fig. 13a3) at those $T_{\mathrm{v}}$. PToF / MS for $\mathrm{NaNO}_{3}$ increased continuously until reaching 1 at 500 and $550^{\circ} \mathrm{C}$ for the $\mathrm{CV}$ and $\mathrm{SV}$ respectively (Fig. 15b), which is consistent with the PToF widths vs. $T_{\mathrm{v}}$ (Fig. 13b1-3). For sulfate (Fig. 15c), the PToF/MS ratio in both vapourizers increased with $T_{\mathrm{v}}$ between 300 and $800^{\circ} \mathrm{C}$. This increase was mainly associated with faster vapourization/detection. 

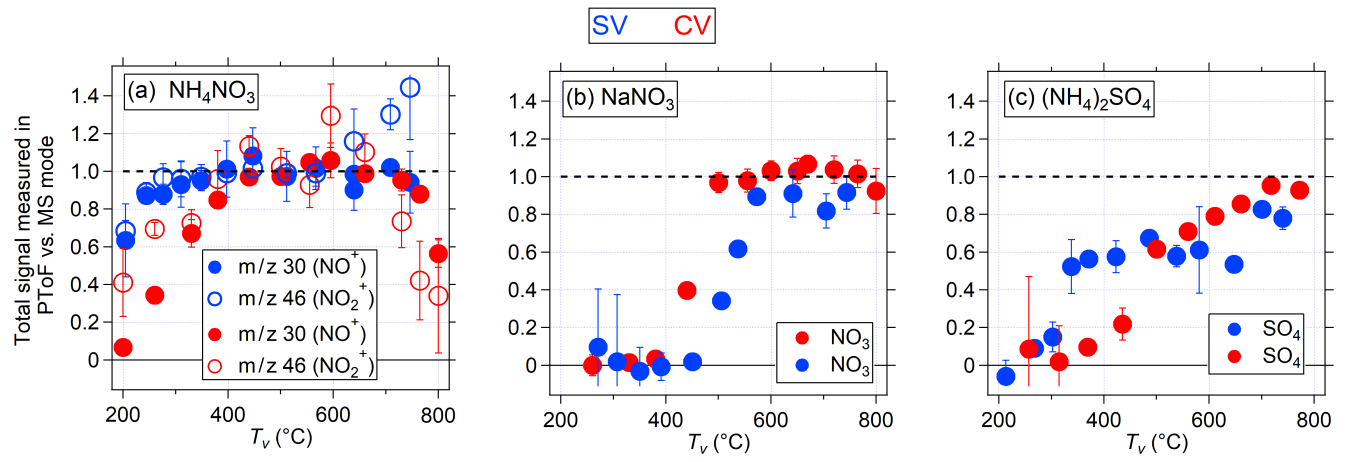

Figure 15. Ratio of total signals measured in PToF vs. MS mode for (a) $\left(\mathrm{NH}_{4}\right)_{2} \mathrm{SO}_{4}$, (b) $\mathrm{NH}_{4} \mathrm{NO}_{3}$ and $(\mathbf{c}) \mathrm{NaNO}_{3}$ in the $\mathrm{SV}$ and $\mathrm{CV}$ as a function of $T_{\mathrm{V}}$.

Based on all the $T_{\mathrm{v}}$-dependent experiments discussed above, we recommend an operating $T_{\mathrm{V}} \sim 500-550{ }^{\circ} \mathrm{C}$ for the $\mathrm{CV}$ for normal usage. In this temperature range, fast vapourization of inorganic particles with high CE and reduced distortion of PToF distributions are observed, while fragmentation (including of organic species) is less increased, and slower response effects observed at high $T_{\mathrm{v}}\left(\mathrm{e} . \mathrm{g} .>700^{\circ} \mathrm{C}\right)$ can be avoided.

\section{Conclusions}

To reduce the quantification uncertainty of non-refractory aerosols due to particle bounce in the AMS, a CV has been designed with the goal of trapping particles inside the vapourizer body to achieve near unity collection efficiency, thereby reducing one of the largest uncertainties associated with the AMS quantification which is particle bounce.

The performance of the $\mathrm{CV}$ was quantified and compared with the $\mathrm{SV}$ for four inorganic standard species $\mathrm{NH}_{4} \mathrm{NO}_{3}$, $\mathrm{NaNO}_{3},\left(\mathrm{NH}_{4}\right)_{2} \mathrm{SO}_{4}$ and $\mathrm{NH}_{4} \mathrm{Cl}$, representative of ambient nitrate, sulfate, ammonium and chloride species. The whole range of practical $T_{\mathrm{V}}\left(200-800^{\circ} \mathrm{C}\right)$ was explored. The main conclusions are as follows.

Thermal decomposition is a key step in aerosol detection in the AMS. The fragmentation patterns of inorganic species in the CV shift toward smaller mass fragments compared with the SV. This shift is caused by a greater degree of thermal decomposition in the vapourizer due to the increased residence time of condensed and/or vapour phase molecules on the walls of the $\mathrm{CV}$.

Multiple results support the unlikelihood that a dominant fraction of $\mathrm{NH}_{4} \mathrm{NO}_{3},\left(\mathrm{NH}_{4}\right)_{2} \mathrm{SO}_{4}$ and $\mathrm{NH}_{4} \mathrm{Cl}$ vapourize as intact molecular species, but rather that they first decompose to $\mathrm{NH}_{3}(\mathrm{~g})+$ acids (and other anion product species).

The $\mathrm{CE}$ of $\mathrm{NH}_{4} \mathrm{NO}_{3}, \mathrm{NaNO}_{3},\left(\mathrm{NH}_{4}\right)_{2} \mathrm{SO}_{4}$ and $\mathrm{NH}_{4} \mathrm{Cl}$ in the $\mathrm{CV}$ at $500-600^{\circ} \mathrm{C}$ were $\sim 1, \sim 0.95, \sim 0.8$ and $\sim 0.35$ respectively, which are comparable to or higher than those in the $\mathrm{SV}(\sim 1, \sim 0.85, \sim 0.4$, and $\sim 0.25)$, indicating a reduced fraction of particle loss due to bouncing in the CV. Although the $\mathrm{CE}$ of some pure inorganic species were still less than 1 in the $\mathrm{CV}$, a higher $\mathrm{CE}(\sim 1)$ has been observed for ambient internally mixed particles (Hu et al., 2017).

In this study, we found a temperature-dependent trend of the mass ratio between $\mathrm{CO}_{2}^{+}$produced and $\mathrm{NO}_{3}$ sampled in the SV (1-10\%) likely due to catalytic reactions liberating charred carbon on the vapourizer. In the $\mathrm{CV}$, negligible $\mathrm{CO}_{2}^{+}(<0.4 \%)$ was formed when sampling $\mathrm{NH}_{4} \mathrm{NO}_{3}$ particles. $\mathrm{NaNO}_{3}$ particle in the $\mathrm{CV}$ can produce a comparable amount of $\mathrm{CO}_{2}^{+}$per $\mathrm{NO}_{3}$ mass to the $\mathrm{SV}$ (up to $10 \%$ ) when the $\mathrm{CV}$ has been recently exposed to high level of OA. Note that these $\mathrm{CO}_{2}^{+} / \mathrm{NO}_{3}$ ratios can be highly dependent on each individual instrument and its recent sampling history. In ambient air with typically negligible or very small submicron $\mathrm{NaNO}_{3}$ concentrations, this $\mathrm{CO}_{2}^{+}$artefact should be much smaller for the CV than for the SV, and thus have a much lower interference for OA concentration and properties. It could also improve organic $\mathrm{CO}_{2}$ quantification in source studies where ammonium nitrate $\gg \mathrm{OA}$ (such as chamber studies with vehicle exhaust, Pieber et al., 2016).

The PToF distributions of species measured using the CV are broadened, which will reduce the size resolution. This effect will be most important for laboratory experiments with monodisperse particles. For ambient air with typically broad size distributions, size distributions measured from an AMS using the CV are expected to be useful (Hu et al., 2017). A method for estimating whether a pure species can be detected by the AMS sizing mode at a given $T_{\mathrm{V}}$ is proposed.

Particle-beam position-dependent results showed that particle detection with the $\mathrm{CV}$ resembles the detection using the $\mathrm{SV}$ for $\mathrm{NH}_{4} \mathrm{NO}_{3}$, when the particle beam is focused on the edge of the CV. Minimal distortion in the PToF measurement can be achieved under this condition. For practical usage, this set up may be useful to increase size resolution in laboratory studies with monodisperse particles. Whether this benefit extends to less-volatile species should be investigated in future studies. 
Based on all the results of $T_{\mathrm{V}}$-dependent experiments, a $T_{\mathrm{V}}$ $\sim 500-550^{\circ} \mathrm{C}$ for the $\mathrm{CV}$ is recommended.

Data availability. Data can be obtained from the authors upon request (jose.jimenez@colorado.edu)

\section{The Supplement related to this article is available online at https://doi.org/10.5194/amt-10-2897-2017-supplement.}

Competing interests. The authors declare that they have no conflict of interest.

Acknowledgements. This study was partially supported by NSF AGS-1360834, AGS-1243354, NASA NNX15AT96G, DOE (BER/ASR) DE-SC0011105, DE-SC0016559, NOAA NA13OAR4310063 and DOE Small Business Innovative Research (SBIR) contract \#DE-SC0001673. We sincerely thank Melissa Ugelow, Hyungu Kang, Jason Schroder and Benjamin Nault of CU-Boulder for support in specific experiments.

Edited by: Hartmut Herrmann

Reviewed by: Laurent Poulain and one anonymous referee

\section{References}

Allan, J. D., Alfarra, M. R., Bower, K. N., Williams, P. I., Gallagher, M. W., Jimenez, J. L., McDonald, A. G., Nemitz, E., Canagaratna, M. R., Jayne, J. T., Coe, H., and Worsnop, D. R.: Quantitative sampling using an Aerodyne aerosol mass spectrometer - 2. Measurements of fine particulate chemical composition in two U.K. cities, J. Geophys. Res.-Atmos., 108, 4091, https://doi.org/10.1029/2002jd002359, 2003a.

Allan, J. D., Jimenez, J. L., Williams, P. I., Alfarra, M. R., Bower, K. N., Jayne, J. T., Coe, H., and Worsnop, D. R.: Quantitative sampling using an Aerodyne aerosol mass spectrometer: 1. Techniques of data interpretation and error analysis, J. Geophys. Res., 108, 4090, https://doi.org/10.1029/2002JD002358, 2003b.

Allan, J. D., Bower, K. N., Coe, H., Boudries, H., Jayne, J. T., Canagaratna, M. R., Millet, D. B., Goldstein, A. H., Quinn, P. K., Weber, R. J., and Worsnop, D. R.: Submicron aerosol composition at Trinidad Head, California, during ITCT 2K2: Its relationship with gas phase volatile organic carbon and assessment of instrument performance, J. Geophys. Res., 109, D23S24, https://doi.org/10.1029/2003jd004208, 2004a.

Allan, J. D., Delia, A. E., Coe, H., Bower, K. N., Alfarra, M. R., Jimenez, J. L., Middlebrook, A. M., Drewnick, F., Onasch, T. B., Canagaratna, M. R., Jayne, J. T., and Worsnop, D. R.: A generalised method for the extraction of chemically resolved mass spectra from aerodyne aerosol mass spectrometer data, J. Aerosol Sci., 35, 909-922, https://doi.org/10.1016/j.jaerosci.2004.02.007, 2004b.
Bae, M. S., Schwab, J. J., Zhang, Q., Hogrefe, O., Demerjian, K. L., Weimer, S., Rhoads, K., Orsini, D., Venkatachari, P., and Hopke, P. K.: Interference of organic signals in highly time resolved nitrate measurements by low mass resolution aerosol mass spectrometry, J. Geophys. Res., 112, D22305, https://doi.org/10.1029/2007jd008614, 2007.

Bahreini, R., Keywood, M. D., Ng, N. L., Varutbangkul, V., Gao, S., Flagan, R. C., Seinfeld, J. H., Worsnop, D. R., and Jimenez, J. L.: Measurements of Secondary Organic Aerosol from Oxidation of Cycloalkenes, Terpenes, and $\mathrm{m}$-Xylene Using an Aerodyne Aerosol Mass Spectrometer, Environ. Sci. Technol., 39, 5674 5688, https://doi.org/10.1021/es048061a, 2005.

Bahreini, R., Dunlea, E. J., Matthew, B. M., Simons, C., Docherty, K. S., DeCarlo, P. F., Jimenez, J. L., Brock, C. A., and Middlebrook, A. M.: Design and operation of a pressure-controlled inlet for airborne sampling with an aerodynamic aerosol lens, Aerosol Sci. Tech., 42, 465-471, https://doi.org/10.1080/02786820802178514, 2008.

Bahreini, R., Ervens, B., Middlebrook, A. M., Warneke, C., de Gouw, J. A., DeCarlo, P. F., Jimenez, J. L., Brock, C. A., Neuman, J. A., Ryerson, T. B., Stark, H., Atlas, E., Brioude, J., Fried, A., Holloway, J. S., Peischl, J., Richter, D., Walega, J., Weibring, P., Wollny, A. G., and Fehsenfeld, F. C.: Organic aerosol formation in urban and industrial plumes near Houston and Dallas, Texas, J. Geophys. Res.-Atmos., 114, D00F16, https://doi.org/10.1029/2008jd011493, 2009.

Bruns, E. A., Perraud, V., Zelenyuk, A., Ezell, M. J., Johnson, S. N., Yu, Y., Imre, D., Finlayson-Pitts, B. J., and Alexander, M. L.: Comparison of FTIR and Particle Mass Spectrometry for the Measurement of Particulate Organic Nitrates, Environ. Sci. Technol., 44, 1056-1061, https://doi.org/10.1021/es9029864, 2010.

Canagaratna, M. R., Jayne, J. T., Jimenez, J. L., Allan, J. D., Alfarra, M. R., Zhang, Q., Onasch, T. B., Drewnick, F., Coe, H., Middlebrook, A., Delia, A., Williams, L. R., Trimborn, A. M., Northway, M. J., DeCarlo, P. F., Kolb, C. E., Davidovits, P., and Worsnop, D. R.: Chemical and microphysical characterization of ambient aerosols with the aerodyne aerosol mass spectrometer, Mass Spectrom. Rev., 26, 185-222, https://doi.org/10.1002/Mas.20115, 2007.

Canagaratna, M. R., Jimenez, J. L., Kroll, J. H., Chen, Q., Kessler, S. H., Massoli, P., Hildebrandt Ruiz, L., Fortner, E., Williams, L. R., Wilson, K. R., Surratt, J. D., Donahue, N. M., Jayne, J. T., and Worsnop, D. R.: Elemental ratio measurements of organic compounds using aerosol mass spectrometry: characterization, improved calibration, and implications, Atmos. Chem. Phys., 15, 253-272, https://doi.org/10.5194/acp-15-253-2015, 2015.

DeCarlo, P. F., Slowik, J. G., Worsnop, D. R., Davidovits, P., and Jimenez, J. L.: Particle morphology and density characterization by combined mobility and aerodynamic diameter measurements. Part 1: Theory, Aerosol Sci. Tech., 38, 1185-1205, https://doi.org/10.1080/027868290903907, 2004.

DeCarlo, P. F., Kimmel, J. R., Trimborn, A., Northway, M. J., Jayne, J. T., Aiken, A. C., Gonin, M., Fuhrer, K., Horvath, T., Docherty, K. S., Worsnop, D. R., and Jimenez, J. L.: Field-deployable, high-resolution, time-of-flight aerosol mass spectrometer, Anal. Chem., 78, 8281-8289, https://doi.org/10.1021/Ac061249n, 2006.

Docherty, K. S., Aiken, A. C., Huffman, J. A., Ulbrich, I. M., DeCarlo, P. F., Sueper, D., Worsnop, D. R., Snyder, D. C., Peltier, 
R. E., Weber, R. J., Grover, B. D., Eatough, D. J., Williams, B. J., Goldstein, A. H., Ziemann, P. J., and Jimenez, J. L.: The 2005 Study of Organic Aerosols at Riverside (SOAR-1): instrumental intercomparisons and fine particle composition, Atmos. Chem. Phys., 11, 12387-12420, https://doi.org/10.5194/acp-11-123872011, 2011.

Docherty, K. S., Jaoui, M., Corse, E., Jimenez, J. L., Offenberg, J. H., Lewandowski, M., and Kleindienst, T. E.: Collection Efficiency of the Aerosol Mass Spectrometer for ChamberGenerated Secondary Organic Aerosols, Aerosol Sci. Tech., 47, 294-309, https://doi.org/10.1080/02786826.2012.752572, 2012.

Docherty, K. S., Lewandowski, M., and Jimenez, J. L.: Effect of Vaporizer Temperature on Ambient Non-Refractory Submicron Aerosol Composition and Mass Spectra Measured by the Aerosol Mass Spectrometer, Aerosol Sci. Tech., 49, 485-494, https://doi.org/10.1080/02786826.2015.1042100, 2015.

Drewnick, F., Schwab, J. J., Hogrefe, O., Peters, S., Husain, L., Diamond, D., Weber, R., and Demerjian, K. L.: Intercomparison and evaluation of four semi-continuous $\mathrm{PM}_{2.5}$ sulfate instruments, Atmos. Environ., 37, 3335-3350, https://doi.org/10.1016/S13522310(03)00351-0, 2003.

Drewnick, F., Jayne, J. T., Canagaratna, M., Worsnop, D. R., and Demerjian, K. L.: Measurement of ambient aerosol composition during the PMTACS-NY 2001 using an aerosol mass spectrometer. Part II: Chemically speciated mass distributions, Aerosol Sci. Tech., 38, 104-117, https://doi.org/10.1080/02786820390229534, 2004a.

Drewnick, F., Schwab, J. J., Jayne, J. T., Canagaratna, M., Worsnop, D. R., and Demerjian, K. L.: Measurement of ambient aerosol composition during the PMTACS-NY 2001 using an aerosol mass spectrometer. Part I: Mass concentrations, Aerosol Sci. Tech., 38, 92-103, https://doi.org/10.1080/02786820390229507, 2004b.

Drewnick, F., Diesch, J.-M., Faber, P., and Borrmann, S.: Aerosol mass spectrometry: particle-vaporizer interactions and their consequences for the measurements, Atmos. Meas. Tech., 8, 38113830, https://doi.org/10.5194/amt-8-3811-2015, 2015.

Farmer, D. K. and Jimenez, J. L.: Real-time Atmospheric Chemistry Field Instrumentation, Anal. Chem., 82, 7879-7884, https://doi.org/10.1021/Ac1010603, 2010.

Friedel, R. A., Shultz, J. L., and Sharkey, A. G.: Mass Spectrum of Nitric Acid, Anal. Chem., 31, 1128-1128, https://doi.org/10.1021/ac60150a615, 1959.

Fry, J. L., Draper, D. C., Zarzana, K. J., Campuzano-Jost, P., Day, D. A., Jimenez, J. L., Brown, S. S., Cohen, R. C., Kaser, L., Hansel, A., Cappellin, L., Karl, T., Hodzic Roux, A., Turnipseed, A., Cantrell, C., Lefer, B. L., and Grossberg, N.: Observations of gas- and aerosol-phase organic nitrates at BEACHON-RoMBAS 2011, Atmos. Chem. Phys., 13, 85858605, https://doi.org/10.5194/acp-13-8585-2013, 2013.

Fuzzi, S., Baltensperger, U., Carslaw, K., Decesari, S., Denier van der Gon, H., Facchini, M. C., Fowler, D., Koren, I., Langford, B., Lohmann, U., Nemitz, E., Pandis, S., Riipinen, I., Rudich, Y., Schaap, M., Slowik, J. G., Spracklen, D. V., Vignati, E., Wild, M., Williams, M., and Gilardoni, S.: Particulate matter, air quality and climate: lessons learned and future needs, Atmos. Chem. Phys., 15, 8217-8299, 10.5194/acp-15-8217-2015, 2015.

Hallquist, M., Wenger, J. C., Baltensperger, U., Rudich, Y., Simpson, D., Claeys, M., Dommen, J., Donahue, N. M., George,
C., Goldstein, A. H., Hamilton, J. F., Herrmann, H., Hoffmann, T., Iinuma, Y., Jang, M., Jenkin, M. E., Jimenez, J. L., Kiendler-Scharr, A., Maenhaut, W., McFiggans, G., Mentel, Th. F., Monod, A., Prévôt, A. S. H., Seinfeld, J. H., Surratt, J. D., Szmigielski, R., and Wildt, J.: The formation, properties and impact of secondary organic aerosol: current and emerging issues, Atmos. Chem. Phys., 9, 5155-5236, https://doi.org/10.5194/acp9-5155-2009, 2009.

Haynes, W.: CRC Handbook of Chemistry and Physics, 96th Edn., CRC Press, 2015.

Heal, M. R., Kumar, P., and Harrison, R. M.: Particles, air quality, policy and health, Chem. Soc. Rev., 41, 6606-6630, 2012.

Hogrefe, O., Drewnick, F., Lala, G. G., Schwab, J. J., and Demerjian, K. L.: Development, operation and applications of an aerosol generation, calibration and research facility, Aerosol Sci. Tech., 38, 196-214, https://doi.org/10.1080/02786820390229516, 2004.

Hu, W., Hu, M., Hu, W., Jimenez, J. L., Yuan, B., Chen, W., Wang, M., Wu, Y., Chen, C., Wang, Z., Peng, J., Zeng, L., and Shao, M.: Chemical composition, sources and aging process of sub-micron aerosols in Beijing: contrast between summer and winter, J. Geophys. Res.-Atmos., 121, 1955-1977, https://doi.org/10.1002/2015jd024020, 2016.

Hu, W., Campuzano-Jost, P., Day, D. A., Croteau, P., Canagaratna, M. R., Jayne, J. T., Worsnop, D. R., and Jimenez, J. L.: Evaluation of the new capture vaporizer for aerosol mass spectrometers (AMS) through field studies of inorganic species, Aerosol Sci. Tech., 51, 735-754, https://doi.org/10.1080/02786826.2017.1296104, 2017.

Huffman, J. A., Jayne, J. T., Drewnick, F., Aiken, A. C., Onasch, T., Worsnop, D. R., and Jimenez, J. L.: Design, modeling, optimization, and experimental tests of a particle beam width probe for the aerodyne aerosol mass spectrometer, Aerosol Sci. Tech., 39, 1143-1163, https://doi.org/10.1080/02786820500423782, 2005.

Huffman, J. A., Docherty, K. S., Aiken, A. C., Cubison, M. J., U1brich, I. M., DeCarlo, P. F., Sueper, D., Jayne, J. T., Worsnop, D. R., Ziemann, P. J., and Jimenez, J. L.: Chemically-resolved aerosol volatility measurements from two megacity field studies, Atmos. Chem. Phys., 9, 7161-7182, https://doi.org/10.5194/acp9-7161-2009, 2009a.

Huffman, J. A., Ziemann, P. J., Jayne, J. T., Worsnop, D. R., and Jimenez, J. L.: Development and Characterization of a Fast-Stepping/Scanning Thermodenuder for Chemically-Resolved Aerosol Volatility Measurements (vol 42, pg 395, 2008), Aerosol Sci. Tech., 43, 273-273, https://doi.org/10.1080/02786820802616885, 2009 b.

IPCC: Climate Change 2013: The Physical Science Basis. Contribution of Working Group I to the Fifth Assessment Report of the Intergovernmental Panel on Climate Change, Cambridge University Press, Cambridge, United Kingdom and New York, NY, USA, 1535 pp., 2013.

Jayne, J. T. and Worsnop, D. R.: Particle capture device, Aerodyne Research, Inc., 20150040689 A1, 2016.

Jayne, J. T., Leard, D. C., Zhang, X. F., Davidovits, P., Smith, K. A., Kolb, C. E., and Worsnop, D. R.: Development of an aerosol mass spectrometer for size and composition analysis of submicron particles, Aerosol. Sci. Tech., 33, 49-70, 2000.

Jimenez, J. L., Jayne, J. T., Shi, Q., Kolb, C. E., Worsnop, D. R., Yourshaw, I., Seinfeld, J. H., Flagan, R. C., Zhang, 
X. F., Smith, K. A., Morris, J. W., and Davidovits, P.: Ambient aerosol sampling using the Aerodyne Aerosol Mass Spectrometer, J. Geophys. Res.-Atmos., 108, 8425, https://doi.org/10.1029/2001jd001213, 2003.

Jimenez, J. L., Canagaratna, M. R., Donahue, N. M., Prevot, A. S. H., Zhang, Q., Kroll, J. H., DeCarlo, P. F., Allan, J. D., Coe, H., Ng, N. L., Aiken, A. C., Docherty, K. S., Ulbrich, I. M., Grieshop, A. P., Robinson, A. L., Duplissy, J., Smith, J. D., Wilson, K. R., Lanz, V. A., Hueglin, C., Sun, Y. L., Tian, J., Laaksonen, A., Raatikainen, T., Rautiainen, J., Vaattovaara, P., Ehn, M., Kulmala, M., Tomlinson, J. M., Collins, D. R., Cubison, M. J., Dunlea, E. J., Huffman, J. A., Onasch, T. B., Alfarra, M. R., Williams, P. I., Bower, K., Kondo, Y., Schneider, J., Drewnick, F., Borrmann, S., Weimer, S., Demerjian, K., Salcedo, D., Cottrell, L., Griffin, R., Takami, A., Miyoshi, T., Hatakeyama, S., Shimono, A., Sun, J. Y., Zhang, Y. M., Dzepina, K., Kimmel, J. R., Sueper, D., Jayne, J. T., Herndon, S. C., Trimborn, A. M., Williams, L. R., Wood, E. C., Middlebrook, A. M., Kolb, C. E., Baltensperger, U., and Worsnop, D. R.: Evolution of Organic Aerosols in the Atmosphere, Science, 326, 1525-1529, https://doi.org/10.1126/science.1180353, 2009.

Jimenez, J. L., Canagaratna, M. R., Drewnick, F., Allan, J. D., Alfarra, M. R., Middlebrook, A. M., Slowik, J. G., Zhang, Q., Coe, H., Jayne, J. T., and Worsnop, D. R.: Comment on "The effects of molecular weight and thermal decomposition on the sensitivity of a thermal desorption aerosol mass spectrometer", Aerosol Sci. Tech., 50, i-xv, https://doi.org/10.1080/02786826.2016.1205728, 2016.

Kang, M., Cho, H.-J., Kwak, H., and Park, K.: Evaluation of Particle Bounce in Various Collection Substrates to be Used as Vaporizer in Aerosol Mass Spectrometer, Aerosol Sci. Tech., 49, 332-339, https://doi.org/10.1080/02786826.2015.1028518, 2015.

Knote, C., Brunner, D., Vogel, H., Allan, J., Asmi, A., Äijälä, M., Carbone, S., van der Gon, H. D., Jimenez, J. L., Kiendler-Scharr, A., Mohr, C., Poulain, L., Prévôt, A. S. H., Swietlicki, E., and Vogel, B.: Towards an online-coupled chemistry-climate model: evaluation of trace gases and aerosols in COSMO-ART, Geosci. Model Dev., 4, 1077-1102, https://doi.org/10.5194/gmd-4-10772011, 2011.

Linstrom, P. J. and Mallard, W. G.: NIST Chemistry WebBook, NIST Standard Reference Database Number 69, 2016.

Liu, P., Ziemann, P. J., Kittelson, D. B., and Mcmurry, P. H.: Generating Particle Beams of Controlled Dimensions and Divergence .1. Theory of Particle Motion in Aerodynamic Lenses and Nozzle Expansions, Aerosol Sci. Tech., 22, 293-313, 1995a.

Liu, P., Ziemann, P. J., Kittelson, D. B., and McMurry, P. H.: Generating Particle Beams of Controlled Dimensions and Divergence: II. Experimental Evaluation of Particle Motion in Aerodynamic Lenses and Nozzle Expansions, Aerosol Sci. Tech., 22, 314-324, https://doi.org/10.1080/02786829408959749, 1995 b.

Liu, P. S. K., Deng, R., Smith, K. A., Williams, L. R., Jayne, J. T., Canagaratna, M. R., Moore, K., Onasch, T. B., Worsnop, D. R., and Deshler, T.: Transmission efficiency of an aerodynamic focusing lens system: Comparison of model calculations and laboratory measurements for the Aerodyne Aerosol Mass Spectrometer, Aerosol Sci. Tech., 41, 721-733, https://doi.org/10.1080/02786820701422278, 2007.

Matthew, B. M., Middlebrook, A. M., and Onasch, T. B.: Collection efficiencies in an Aerodyne Aerosol Mass
Spectrometer as a function of particle phase for laboratory generated aerosols, Aerosol Sci. Tech., 42, 884-898, https://doi.org/10.1080/02786820802356797, 2008.

McLafferty, F. W. and Turecek, F.: Interpretation of mass spectra, University science books, 1993.

Middlebrook, A. M., Bahreini, R., Jimenez, J. L., and Canagaratna, M. R.: Evaluation of Composition-Dependent Collection Efficiencies for the Aerodyne Aerosol Mass Spectrometer using Field Data, Aerosol Sci. Tech., 46, 258-271, https://doi.org/10.1080/02786826.2011.620041, 2012.

Murphy, D. M.: The effects of molecular weight and thermal decomposition on the sensitivity of a thermal desorption aerosol mass spectrometer, Aerosol Sci. Tech., 50, 118-125, https://doi.org/10.1080/02786826.2015.1136403, 2016.

Murphy, D. M.: Interactive comment on "Evaluation of the new capture vaporizer for Aerosol Mass Spectrometers (AMS) through laboratory studies of inorganic species" by Weiwei Hu et al., Atmos. Meas. Tech. Discuss., https://doi.org/10.5194/amt-2016337-SC2, 2017.

Ozawa, Y., Takeda, N., Miyakawa, T., Takei, M., Hirayama, N., and Takegawa, N.: Evaluation of a particle trap laser desorption mass spectrometer (PT-LDMS) for the quantification of sulfate aerosols, Aerosol Sci. Tech., 50, 173-186, https://doi.org/10.1080/02786826.2016.1139685, 2016.

Pieber, S. M., El Haddad, I., Slowik, J. G., Canagaratna, M. R., Jayne, J. T., Platt, S. M., Bozzetti, C., Daellenbach, K. R., Fröhlich, R., Vlachou, A., Klein, F., Dommen, J., Miljevic, B., Jiménez, J. L., Worsnop, D. R., Baltensperger, U., and Prévôt, A. S. H.: Inorganic Salt Interference on $\mathrm{CO}_{2}^{+}$in Aerodyne AMS and ACSM Organic Aerosol Composition Studies, Environ Sci. Technol., 50, 10494-10503, https://doi.org/10.1021/acs.est.6b01035, 2016.

Quinn, P. K., Bates, T. S., Coffman, D., Onasch, T. B., Worsnop, D., Baynard, T., de Gouw, J. A., Goldan, P. D., Kuster, W. C., Williams, E., Roberts, J. M., Lerner, B., Stohl, A., Pettersson, A., and Lovejoy, E. R.: Impacts of sources and aging on submicrometer aerosol properties in the marine boundary layer across the Gulf of Maine, J. Geophys. Res., 111, D23S36, https://doi.org/10.1029/2006JD007582, 2006.

Robinson, E. S., Onasch, T. B., Worsnop, D., and Donahue, N. M.: Collection efficiency of a-pinene secondary organic aerosol particles explored via light-scattering single-particle aerosol mass spectrometry, Atmos. Meas. Tech., 10, 1139-1154, https://doi.org/10.5194/amt-10-1139-2017, 2017.

Salcedo, D., Onasch, T. B., Canagaratna, M. R., Dzepina, K., Huffman, J. A., Jayne, J. T., Worsnop, D. R., Kolb, C. E., Weimer, S., Drewnick, F., Allan, J. D., Delia, A. E., and Jimenez, J. L.: Technical Note: Use of a beam width probe in an Aerosol Mass Spectrometer to monitor particle collection efficiency in the field, Atmos. Chem. Phys., 7, 549-556, https://doi.org/10.5194/acp-7549-2007, 2007.

Saleh, R., Robinson, E. S., Ahern, A. T., and Donahue, N. M.: Evaporation rate of particles in the vaporizer of the Aerodyne aerosol mass spectrometer, Aerosol Sci. Tech., 51, 501-508, https://doi.org/10.1080/02786826.2016.1271109, 2017.

Takegawa, N., Miyakawa, T., Watanabe, M., Kondo, Y., Miyazaki, Y., Han, S., Zhao, Y., van Pinxteren, D., Bruggemann, E., Gnauk, T., Herrmann, H., Xiao, R., Deng, Z., Hu, M., Zhu, T., and Zhang, Y.: Performance of an Aerodyne Aerosol Mass 
Spectrometer (AMS) during Intensive Campaigns in China in the Summer of 2006, Aerosol Sci. Tech., 43, 189-204, https://doi.org/10.1080/02786820802582251, 2009.

Takegawa, N., Miyakawa, T., Nakamura, T., Sameshima, Y., Takei, M., Kondo, Y., and Hirayama, N.: Evaluation of a New Particle Trap in a Laser Desorption Mass Spectrometer for Online Measurement of Aerosol Composition, Aerosol Sci. Tech., 46, 428-443, https://doi.org/10.1080/02786826.2011.635727, 2012.

Turpin, B. J., Saxena, P., and Andrews, E.: Measuring and simulating particulate organics in the atmosphere: problems and prospects, Atmos. Environ., 34, 2983-3013, 2000.

Wang, Z., Lu, P., Zhang, X., Wang, L., Li, Q., and Zhang, Z.: NOx storage and soot combustion over well-dispersed mesoporous mixed oxides via hydrotalcite-like precursors, RSC Advances, 5, 52743-52753, 10.1039/c5ra07414b, 2015.

Weimer, S., Drewnick, F., Hogrefe, O., Schwab, J. J., Rhoads, K., Orsini, D., Canagaratna, M., Worsnop, D. R., and Demerjian, K. L.: Size-selective nonrefractory ambient aerosol measurements during the Particulate Matter Technology Assessment and Characterization Study - New York 2004 Winter Intensive in New York City, J. Geophys. Res., 111, D18305, https://doi.org/10.1029/2006jd007215, 2006.
Williams, L.: How to set your vaporizer temperature/variablility in mass spectral signatures, available at: http://cires1.colorado.edu/jimenez-group/UsrMtgs/UsersMtg11/ WilliamsAMSUsersMtg_2010_VapT.pdf, AMS User's Meeting, Hyytiala, Finland, last update: June 2016, 2010.

Xu, W., Croteau, P., Williams, L., Canagaratna, M., Onasch, T., Cross, E., Zhang, X., Robinson, W., Worsnop, D., and Jayne, $\mathrm{J}$.: Laboratory characterization of an aerosol chemical speciation monitor with PM2.5 measurement capability, Aerosol Sci. Tech., 51, 69-83, 10.1080/02786826.2016.1241859, 2017.

Zhu, R. S., Wang, J. H., and Lin, M. C.: Sublimation of Ammonium Salts:? A Mechanism Revealed by a First-Principles Study of the $\mathrm{NH}_{4} \mathrm{Cl}$ System, The J. Phys. Chem. C, 111, 13831-13838, https://doi.org/10.1021/jp073448w, 2007. 